\title{
The Impacts of Pulsed Reintroduction of River Water on a Mississippi Delta Coastal Basin
}

\author{
J.W. Day , J.E. Cable ${ }^{\dagger}$, J.H. Cowan, Jr. ${ }^{\dagger}$, R. DeLaune ${ }^{\dagger}$, K. de Mutsert', B. Fry ${ }^{\dagger}$, H. Mashriqui ${ }^{\dagger}$, D. Justic ${ }^{\dagger}$, \\ P. Kemp ${ }^{\S}$, R.R. Lane ${ }^{\dagger}$ J. Rick ${ }^{\dagger}$, S. Rick , L.P. Rozas ${ }^{\S \S}$, G. Snedden', E. Swenson ${ }^{\dagger}$, R.R. Twilley , and \\ B. Wissel ${ }^{1+\dagger}$ \\ 'Department of Oceanography \\ and Coastal Sciences \\ Louisiana State University \\ Baton Rouge, LA 70803, U.S.A. \\ 楌Metrohm International \\ Headquarters \\ Oberdorfstr. 68, CH-9109 \\ Herisau, Switzerland \\ National Weather Service \\ NOAA \\ 1325 East West Highway \\ (SSMC-2), Room 8410 \\ Silver Spring, MD 20910, \\ U.S.A. \\ ${ }^{\S \S}$ NOAA Fisheries Service \\ SEFSC/Estuarine Habitats \& \\ Coastal Fisheries Center \\ Lafayette, LA 70506, U.S.A. \\ ${ }^{\S}$ National Audubon Society \\ 6160 Perkins Road \\ Baton Rouge, LA 70708, U.S.A. \\ \#AquaEcology \\ Marie-Curie-Strasse 1 \\ 26129 Oldenburg, Germany \\ \#Department of Biology \\ University of Regina \\ Regina, Saskatchewan, \\ S4S 0A2 Canada
}

\begin{abstract}
DAY, J.W.; CABLE, J.E.; COWAN, J.H.; DELAUNE, R.; DE MUTSERT, K.; FRY, B.; MASHRIQUI, H.; JUSTIC, D.; KEMP, P.; LANE, R.R.; RICK, J.; ROZAS, L.P.; SNEDDEN, G.; SWENSON, E.; TWILLEY, R.R., and WISSEL, B., 2009. The impacts of pulsed reintroduction of river water on a Mississippi delta coastal basin. Journal of Coastal Research, SI(54), 225-243. West Palm Beach (Florida), ISSN 0749-0208.

During the twentieth century about $25 \%$ of the wetlands of the Mississippi delta was lost, partially a result of isolation of the river from the delta. River diversions are being implemented to reintroduce river water to the delta plain. We synthesize here the results of extensive studies on a river diversion at Caernarvon, Louisiana, one of the largest diversions in the delta.
\end{abstract}

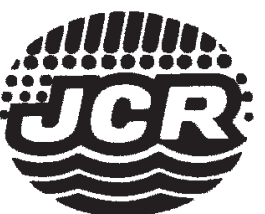

\section{INTRODUCTION}

The Mississippi Delta is one of the largest, and most ecologically and economically important, coastal ecosystems in North America. This $25,000 \mathrm{~km}^{2}$ system includes fresh to saline wetlands, shallow inshore water bodies, and lowelevation uplands, mostly associated with active and abandoned distributary ridges and beach ridges. Delta formation began about 6000 years ago when sea level stabilized after the last ice age. The delta formed as a series of overlapping delta lobes (Roberts, 1997), and like all deltas, it is a result of a very complex set of processes acting at different temporal and spatial scales, including shifting deltaic lobes, crevasse formation, great river floods, hurricanes, annual river floods, weather-front passages, and tides (Boesch et al., 1994; Day et al., 1997, 2000, 2007; Vorosmarty et al., 2009). An increase in wetland area occurred in active deltaic lobes, while wetland loss occurred in abandoned lobes, resulting in a net increase in wetland area over the past several thousand years. During the twentieth century, however, a loss was observed of about $25 \%$ of coastal wetlands or about $4800 \mathrm{~km}^{2}$ (Barras et al., 1994; Britsch and Dunbar, 1993). A variety of factors led to wetland loss, including reduction of sediment input from the basin, pervasive alteration of the hydrology of the deltaic plain, enhanced subsidence due to petroleum extraction, and barrier

DOI: 10.2112 /SI54-015.1. island deterioration. Perhaps most important was the almost complete elimination of river input to the deltaic plain due to flood control levee construction and closure of distributaries that connected the river to the wetlands (Day et al., 2007). The overall trend reveals wetland loss is highest in older delta lobes (e.g., Terrebonne basin) and lowest in areas with active river input (e.g., Atchafalaya). Human-induced changes such as these have had important consequences for delta deterioration worldwide (Day et al., 1995, 1997; Vörösmarty et al., 2009).

A number of restoration approaches have been suggested in Louisiana and are being applied in an attempt to slow or reduce wetland loss. These include major activities such as river diversions, marsh restoration using slurried sediments, and reopening distributaries. Small-scale restoration includes water control structures, marsh terraces, sediment fences, and shoreline protection (Day et al., 2007; Turner and Streever, 2002). River diversions introduce freshwater pulses that combat saltwater intrusion, sediments that directly contribute to accretion, nutrients that stimulate marsh growth, and iron that precipitates toxic sulfides (DeLaune and Pezeshki, 2003; DeLaune et al., 2003). High nutrient levels from river sources also can potentially lead to eutrophication and harmful algal blooms (Turner, Dortch, and Rabalais, 2004). To address issues related to diversions, we carried out a series of integrated studies of the upper Breton Sound estuary, where a river diversion at Caernarvon has introduced river water since 1991. 
The Caernarvon river diversion is one of the largest of many diversions in coastal Louisiana constructed during the last 50 years. Yet, these diversions have received little study. Our interest in Caernarvon was to bring an integrated watershed approach to the study of river diversions, including a coupled physical and ecological set of science measurements and models, while at the same time investigating basic research questions concerning the importance of pulsed events for ecosystem development. Much larger diversions are part of future restoration plans, and experience gained at Caernarvon can inform these larger efforts.

Pulsing is considered essential for most ecosystem functioning and has been called nature's pulsing paradigm (Odum, Odum, and Odum, 1995). For example, understanding river ecosystems has evolved from concepts of the river continuum to those of the flood pulse (Junk and Bayley, 2008; Schram and Eggleton, 2006) and dynamic habitat interactions (Stanford Lorang, and Hauer, 2005). Understanding deltas has evolved from physical-based models (Roberts, 1997) to the concept that deltas are sustained by a hierarchy of energetic forcings (tides, storms, floods) interacting with biogeochemical processes (Day et al., 1995, 1997, 2007). Pulsed storm events along the Louisiana coast appear responsible for much of the net movement and export of material to and from coastal marshes (Baumann, Day, and Miller, 1984; Perez et al., 2000). Floods, tides, hurricanes, and storms are some of the physical events that control flux dynamics of sediments, nutrients, organic materials, and water in coastal systems, and our project focused on the importance of pulsed river water inputs for the Caernarvon watershed and marsh system.

The objective of this article is to provide a synthesis and integration of previous studies on the impact of the Caernarvon river diversion, most of which have been published previously. The information provided is a comprehensive overview of the response of this coastal ecosystem to controlled inputs of river water. Throughout the article, references to published work are provided while unpublished information is discussed in more detail. This approach was used for both methods and data discussion. We measured the effects of inflow pulses from the diversion at different scales, ranging from normal diversions scheduled over 1-2 month periods to special 2-week high-water pulsed diversions. Hydrological studies include studying the distribution of flow within the estuary between marshes and channels as well as the effects of sediment loading and deposition to the estuary. Ecological studies of above- and belowground productivity, biogeochemistry, phytoplankton dynamics, and consumers were conducted. We used stable isotope studies to assay shifts in trophic pathways accompanying diversions and changes in nutrient dynamics, as well as to track the uptake of nitrogen by vegetation. Finally, we used modeling to integrate and synthesize the field studies. Detailed descriptions of individual studies can be found in Delaune et al. (2003); Hyfield et al. (2008); Lane, Day, and Day (2006); Lane, Day, and Thibodeaux (1999); Lane et al. (2004, 2007); Rozas et al. (2005); Snedden, Cable, and Wiseman (2007); Snedden et al. (2007); Swenson et al. (2006); Wissel and Fry (2005); Wissel, Gace, and Fry (2005). Our overall question was how do pulsed introductions of river water affect the functioning of the upper Breton Sound ecosystem? Specific questions included the following:

- How do marine and riverine forcings affect hydrology in the area? How do pulsed river water introductions affect channelized $v s$. over marsh flow?

- Does timing of pulses affect the quantity and distribution of sediments in the system?

- How do concentrations of nutrients change as water flows down basin and does nonconservative uptake of nutrients occur? How does over-marsh flow affect nutrient dynamics?

- How are phytoplankton community composition and chlorophyll concentrations affected by river input?

- How does river input impact food web dynamics and spatial and temporal patterns of nekton distribution?

\section{STUDY AREA}

The Breton Sound estuary is located southeast of New Orleans, Louisiana, on the east side of the Mississippi River and is bounded to the east by the natural levee of Bayou Terre Aux Boeufs and to the west by the Mississippi River levee (Figure 1). Two delta lobes, the St. Bernard (of which Bayou Terre aux Boeufs is a relic channel) and the modern Balize delta, encompass the study area (Roberts, 1997; Scruton, 1960; Welder, 1959). Over the past century, wetlands in the basin have deteriorated as a result of the retreat of the St. Bernard deltaic lobe, leveeing of the Mississippi River, and hydrologic alteration within the estuary (Day et al., 2000; Penland et al., 1988). The present-day estuary is dominated by wetlands in the upper reaches and the lower estuary is primarily the open water of Breton Sound. The Chandeleur Islands are the barrier island system that has protected the estuary from large storms over the past several hundred years, but these islands were seriously damaged during the 2005 Hurricane Katrina storm surge (Barras, 2007). Prior to completion of the levee system, the area received regular large inputs of river water including five large crevasses that occurred during the first quarter of the twentieth century (Davis, 1993, 2000).

Major physical forcings on the estuary are tides, frontal storms, diverted river water, and climate conditions. The diurnal tide range is approximately $0.25 \mathrm{~m}$ in the lower estuary and decreases by an order of magnitude as the tide progresses up estuary. Snedden, Cable, and Wiseman (2007) attributed this decrease to energy loss as the tide progresses through this highly frictional deltaic landscape. Marine endmember forcing also occurs during autumn and winter when cold front passages occur every 4 to 7 days (Chuang and Wiseman, 1983). Amplitudes of coastal water level fluctuations associated with such frontal events typically exceed those forced by astronomical tides. A semiannual cycle in Gulf of Mexico coastal sea level also exists, driven primarily by seasonal wind patterns and thermally driven changes in seawater density. This cycle typically causes high sea levels during spring and early autumn.

The Caernarvon river diversion structure, completed in 1991, is located on the east bank of the Mississippi River at river mile 81.5 (Figure 1), and consists of five 4.6 -m wide box 


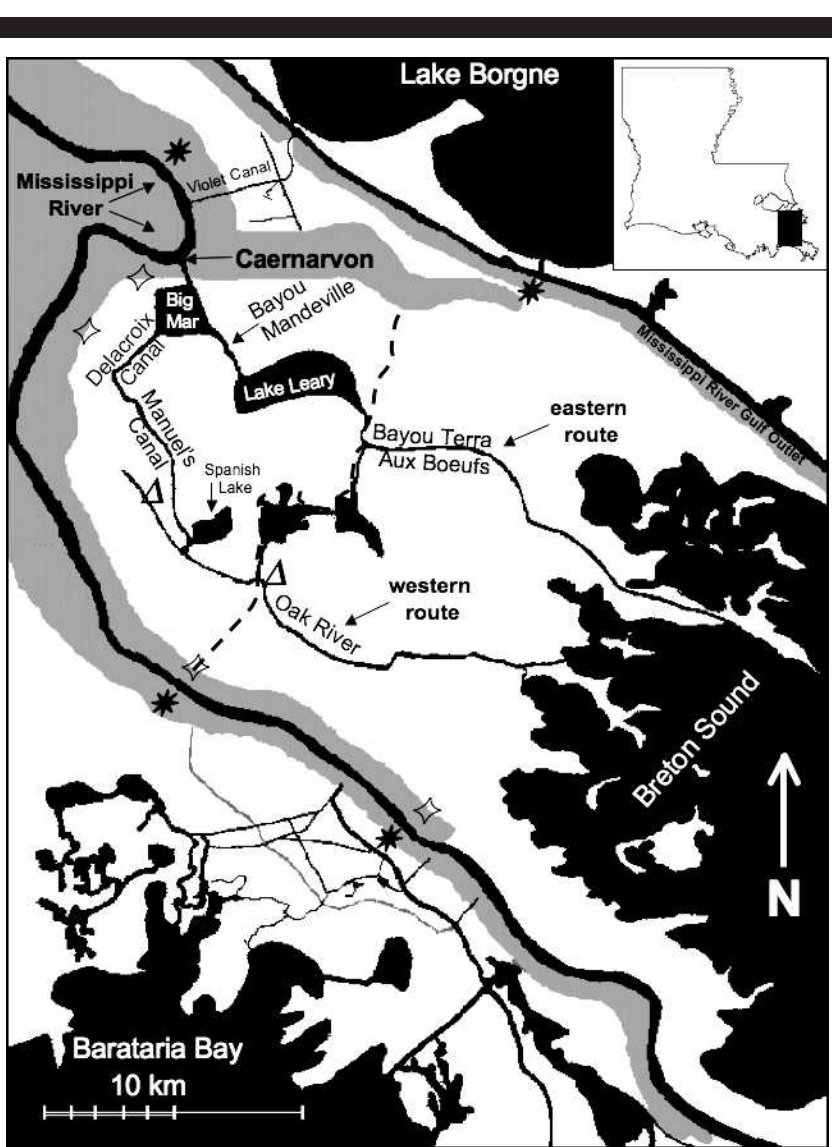

Figure 1. Map of Breton Sound estuary is shown, where Bayou Terre Aux Boeufs is the eastern boundary and the Mississippi River bounds the estuary to the west. The pumped drainage areas are shaded gray. Diamonds show locations of stormwater pumps, triangles are the location of water level recorders, and asterisks are meteorological stations. The dashed black line represents the southern boundary for the upper estuary. The black line represents the down estuary extent of diversion-induced flooding from Hyfield et al. (2008).

culverts with vertical lift gates, with a capability of passing up to $225 \mathrm{~m}^{3} \mathrm{~s}^{-1}$. It is a gravity-fed system that receives water from the river when the stage is greater than $1.2 \mathrm{~m}(\sim 4 \mathrm{ft})$ above sea level. Between the diversion structure and the Gulf of Mexico, there are about $1100 \mathrm{~km}^{2}$ of fresh to saline wetlands intermixed with shallow water bodies. Diverted water must travel $30-40 \mathrm{~km}$ through two major routes dominated by wetlands before reaching the open waters of Breton Sound, and an additional $50 \mathrm{~km}$ before reaching gulf waters (Figure 1). The two major routes are via (1) Bayou Mandeville, Lake Leary, and Bayou Terra aux Boeufs to the east, which typically captures the majority of the discharge, and (2) Delacroix Canal, Manuel's Canal and River aux Chêne to the west, which carries the remaining flow (Snedden et al., 2007). There is, however, extensive marsh flooding during high diversion discharges, frontal passages, and southerly winds. Water depths range from 1 to $1.25 \mathrm{~m}$ in lakes and small bayous to $3.5 \mathrm{~m}$ in the main channels (i.e., the eastern and western routes). The water column is generally well mixed throughout the estuary. Levees prevent Mis-

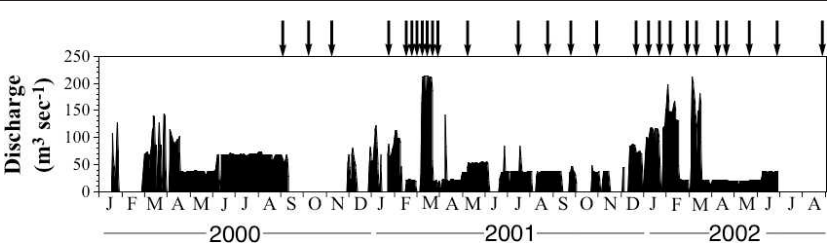

Figure 2. Discharge from the Caernarvon river diversion is shown with arrows to indicate when water quality sampling was conducted.

sissippi River water from entering most of estuary; however, river water can flow directly into Breton Sound below the point where artificial levees end on the eastern bank of the river, which affects some nutrient concentrations and salinity in the outer bays of the estuary (Figure 1).

\section{METHODS}

Measurements were carried out from September 1999 to late August 2004 during varying discharge volumes through the diversion structure. Discharge ranged from 0 to $213 \mathrm{~m}^{3} \mathrm{~s}^{-1}$, with several 2-week experimental pulse discharges (Figure 2). Experimental pulses were performed in cooperation with state and local agencies to deliver a predictable volume of water to the estuary for a fixed amount of time. Additional pulses were released based on the normal operating schedule of the diversion. We designed the experimental pulses to take place in series with experimental low-flow periods so that we sampled during a low flow and a subsequent high flow period. Beginning in late November 2000 , three moderate-sized $\left(\approx 100 \mathrm{~m}^{3} \mathrm{~s}^{-1}\right)$ pulses were released, followed by a large pulse $\left(\approx 200 \mathrm{~m}^{3} \mathrm{~s}^{-1}\right)$ in the spring of 2001. From December 2001 through March 2002 four experimental pulses ranging from about 100 to $200 \mathrm{~m}^{3} \mathrm{~s}^{-1}$ were performed. During the spring pulse of 2001, the freshwater replacement time was 12.6 days because 269 million $\mathrm{m}^{3}$ were discharged compared with the total volume of the upper estuary of 212 million $\mathrm{m}^{3}$ (Swenson et al., 2006).

Freshwater inputs through the Caernarvon diversion were measured hourly with an acoustic Doppler current profiler (ADCP) deployed in the outfall channel. An assessment of how these inputs were conveyed down the estuary was made with additional ADCPs deployed in the eastern (Bayou Mandeville) and western (Delacroix Canal) routes. A mass balance approach was used to determine the volume of diverted river water that bypassed these east and west channelized flow routes and instead was conveyed downestuary over the marsh surface as sheet flow $\left(q_{\text {resid }}\right)$ :

$$
q_{\text {resid }}=q_{\text {div }}-\left(q_{\text {east }}+q_{\text {west }}\right),
$$

where $q_{\text {div }}$ is the discharge of river water entering the estuary at the diversion, and $q_{\text {east }}$ and $q_{\text {west }}$ are the measured discharges at the upper reaches of the east and west flow routes, respectively. It is important to note that $q_{\text {resid }}$ does not indicate specifically where sheet flow is occurring; it simply quantifies the volume of diverted river water not passing the current meters in the upper reaches of the two primary channelized flow routes, which together convey nearly all diverted river water to the lower estuary when structure 
discharge is less than about $100 \mathrm{~m}^{3} \mathrm{~s}^{-1}$. Marsh water level was measured hourly in the upper estuary (Figure 1) to determine if periods of elevated water levels over the marsh coincided with pulsed diversion events and periods when $q_{\text {resid }}$ was high.

Turbidity of diverted Mississippi River water in the outflow channel was measured with an optical backscatter nephelometric turbidity probe (YSI-600 OMS), which was field serviced and calibrated monthly. During routine servicing throughout the study, a total of 47 periodic water samples was obtained from $1 \mathrm{~m}$ below the water surface and subsequently analyzed for TSS. Regression analysis showed the presence of a significant linear relationship $\left(p<0.001 ; r^{2}\right.$ $=0.84 ;$ Snedden et al., 2007) between TSS concentrations obtained from water samples and simultaneously recorded turbidity values, allowing turbidity to be used as a proxy for TSS. Instantaneous flux of Mississippi River sediments into the estuary via the diversion structure $\left(\right.$ flux $\left._{\text {sed }}\right)$ was then computed as

$$
\operatorname{flux}_{\mathrm{sed}}=q_{\text {div }} \times \mathrm{TSS}
$$

where $q_{\text {div }}$ and TSS are the volume discharge and suspended sediment concentrations in the outflow channel, respectively. Total sediment delivery $Q$ over a time interval $0-T$ was determined as

$$
Q=\int_{0}^{T} \text { flux }_{\text {sed }} d t
$$

where $t$ is time.

Sediment accumulation was evaluated over three timescales to estimate the variability in deposition and how it changed through time: (1) short-term (weeks) deposition via sediment traps; (2) moderate term (months to years) deposition via sediment elevation tables; and (3) long-term (decades) deposition via ${ }^{210} \mathrm{~Pb}$ dating. Short-term sediment deposition on the marsh surface was measured over an 18month sampling period in 2001 and 2002 using sediment traps placed on the marsh surface (Reed, 1992; Wheelock, 2003). Sediment traps were placed at varying distances from the diversion $(<6 \mathrm{~km} ; 6-10 \mathrm{~km} ;>10 \mathrm{~km})$ and in interior marsh areas and near the channel edge; they were left in place for 1 to 3 weeks. The traps were collected, and sediment deposition was quantified from the dried mass of accumulated sediment on a trap for the individual deployment period. Wetland surface elevation change and vertical accretion from 1996 to 2000 was measured using a sediment elevation table (SET) and feldspar marker horizons at the Caernarvon diversion (Lane, Day, and Day, 2006) based on methods developed by Boumans and Day (1993) and Cahoon et al. (2000). Sites were established at near, intermediate, and far locations with respect to the diversion. Measurements were made annually. Short-term and moderate deposition were compared with long-term accretion, measured based on excess ${ }^{210} \mathrm{~Pb}$ geochronology in the area near Delacroix Canal, to estimate compaction and the effects of the diversion sediment delivery over varying periods (Lane, Day, and Day, 2006; Wheelock, 2003).
Lane et al. (1999, 2004, 2007) measured spatial and temporal trends in nutrient and hydrographic parameters in the Caernarvon estuary using synoptic water quality transects as well as a flow-through system. Spatial coverage extended from the diversion structure to the southern edge of the wetland complex, and sampling was carried out semimonthly from 1987 to 1994, 1999 to 2004, and 2007 to present. Discrete water samples were collected for the analysis of nitrate + nitrite $\left(\mathrm{NO}_{x}\right)$, ammonia + ammonium $\left(\mathrm{NH}_{x}\right)$, total nitrogen (TN), dissolved inorganic phosphorus (DIP), total phosphorus (TP), dissolved silica (DSi), total suspended sediments (TSS), and salinity (Greenberg et al., 1985). The flow-through system was used during the recent two sampling periods to measure temperature, salinity, fluorescence, and turbidity continuously while boating through the estuary (Lane et al., 2007).

Flumes $4 \mathrm{~m}$ wide and $100 \mathrm{~m}$ long were used to measure sediment-water columns interactions in the marsh (Childers and Day, 1988; Rivera-Monroy et al., 1995). One flume was constructed in the marsh $2.5 \mathrm{~km}$ south of the diversion and was directly affected by diverted river water. Another flume was constructed about $7.5 \mathrm{~km}$ to the south, and nutrient dynamics were measured after diverted water had flowed over the marsh for several kilometers. Water depth, temperature, and nutrient concentrations were measured at each end of the flumes during two pulse events each in February and March of 2004 (Baker, 2005). Fluxes of materials between the sediments and the water column were calculated based on comparing upstream and downstream samples in each flume over 48 hours. Fluxes of nitrogen gas and rates of denitrification were also measured.

Hyfield et al. (2008) developed a water budget and analyzed nutrient inputs from 2000 to 2002 . Total annual loading rates of nitrogen and phosphorus were calculated for the total estuary $\left(848 \mathrm{~km}^{2}\right)$ and for the upper basin $\left(370 \mathrm{~km}^{2}\right)$. They quantified freshwater, nitrogen, and phosphorus inputs to the Breton Sound estuary for three climatically different years (2000, 2001, and 2002). Water budgets included precipitation, potential evapotranspiration, the diversion, stormwater pumps, and groundwater. The water budget was based on data from three meteorological stations adjacent to the estuary. Groundwater input was modeled using continuous records of river stage and estuarine water levels to evaluate seasonal and annual variations in this seepage movement. Darcy's Law was used to estimate the volume of groundwater seepage under the Mississippi River levee. Atmospheric deposition was obtained from meteorological stations in Terrebonne and Iberia parishes (National Atmospheric Deposition Program, 2000-2002) for each year. Annual TP atmospheric data were calculated using data from the literature.

End of season live (EOSL) biomass was measured at 10 to 20 locations in the Breton Sound estuary during the last two weeks of September 1999, 2000, and 2001 (Day et al., 2009). Each location was 10 to $20 \mathrm{~m}$ from the water's edge in an area of relatively homogenous vegetation. Five $0.06-\mathrm{m}^{2}$ clip plots were taken at each location using randomly placed quadrats. Vegetation within the quadrat was cut as close to the marsh surface as possible, stored in labeled paper bags, brought back to the laboratory, and refrigerated until processing. Live 
material was separated from dead, and dried at $60^{\circ} \mathrm{C}$ to a constant weight. All data are presented as live dry weight ( $\mathrm{g}$ dry wt $\mathrm{m}^{-2}$ ). Plant samples for $\delta^{15} \mathrm{~N}$ analysis were taken at the same locations as biomass. Samples were combined from several individual herbaceous plants in the area. In addition, plant samples were taken from three herbaceous species on the bank of the Mississippi River, near the Caernarvon structure, as well as a nearby marsh near Violet, Louisiana, that had no riverine influence. The plant samples were dried, ground, then analyzed for $\delta^{15} \mathrm{~N}$ as describe previously.

To evaluate the effects of altered hydrology and nutrient influx on estuarine phytoplankton, we compared concentrations and stable isotopes of particulate organic matter (POM) in the Breton Sound and Barataria estuaries. Water samples were collected at the same sites as water quality samples in 1-L Nalgene HDP bottles and transferred into ice chests. Within 48 hours, POM was filtered using precombusted $\left(450^{\circ} \mathrm{C}, 4\right.$ hours) $\mathrm{GF} / \mathrm{F}$ filters (pore size $\left.0.7 \mu \mathrm{m}\right)$ and a vacuum manifold. Concentrations of particulate organic carbon (POC) and particulate organic nitrogen $(\mathrm{PON})$, the molar $\mathrm{C}: \mathrm{N}$ ratio, $\delta^{13} \mathrm{C}$, and $\delta^{15} \mathrm{~N}$ were determined using an automated analytical system combining an isotope ratio mass spectrometer (Finnigan Delta Plus) and an elemental analyzer (Carlo Erba NA 1500). Combustion was performed in a single column to reduce dead space and maximize signals (Carmen and Fry, 2002). The column was filled with reduced copper wire of diameter $0.3 \mathrm{~mm}$, and temperature was maintained at $850^{\circ} \mathrm{C}$ to avoid melting of the filters. Isotopic abundances are given as: $\delta X=\left[\left(R_{\text {sample }} / R_{\text {standard }}\right)-1\right] \times 1000$, where $X$ is ${ }^{15} \mathrm{~N}$ for nitrogen and ${ }^{13} \mathrm{C}$ for carbon, and $R$ is ${ }^{15} \mathrm{~N} /{ }^{14} \mathrm{~N}$ for $\delta^{15} \mathrm{~N}$ and ${ }^{13} \mathrm{C} /{ }^{12} \mathrm{C}$ for $\delta^{13} \mathrm{C}$. Isotopic values of POM are reported as $\mathrm{PO}^{13} \mathrm{C}$ and $\mathrm{PO}^{15} \mathrm{~N}$ relative to Peedee Belemnite limestone $(0.0 \%$ ) and air $\mathrm{N}_{2}(0.0 \%)$, respectively. Blank corrections based on analyses of precombusted GF/F filters without POM were made for all elemental and isotopic determinations, and NIST $1577 \mathrm{~b}$ bovine liver was analyzed routinely with samples as a check standard. POM samples were not acidified to remove carbonate because spot checks made by dropping $1 \mathrm{~N} \mathrm{HCl}$ onto wetted filters did not show bubbling that would indicate presence of carbonates (Wissel and Fry, 2005; Wissel, Gace, and Fry, 2005).

We also analyzed stable isotopes of the common local consumers-grass shrimp (Palaemonetes sp.), barnacles (Balanus sp.), and small plankton-feeding fish (bay anchovies, Anchoa mitchilli)—-to evaluate if the altered hydrology and nutrient influx into Breton Sound also affected the forage base (Rozas et al., 2005). Tissue samples of consumers collected near water quality sampling sites were analyzed for carbon, nitrogen, and sulfur isotopic compositions with an integrated system consisting of an elementary analyzer (Carlo Erba, 1500) linked to a Finnigan Delta plus isotope ratio mass spectrometer (Barrie and Prosser, 1996). Results are reported in $\delta$ notation relative to international standards PeeDee Belemnitella americana (VPDB) for $\delta^{13} \mathrm{C}, \mathrm{N}_{2}$ in air for $\delta^{15} \mathrm{~N}$, and Canyon Diablo Troilite (VCDT) for $\delta^{34} \mathrm{~S}$. Isotopic abundances are given as: $\delta X=$ $\left[\left(R_{\text {sample }} / R_{\text {standard }}\right)-1\right] \times 1000$, where $X$ is ${ }^{15} \mathrm{~N},{ }^{13} \mathrm{C}$, or ${ }^{34} \mathrm{~S}$, and $R$ is ${ }^{15} \mathrm{~N} /{ }^{14} \mathrm{~N},{ }^{13} \mathrm{C} /{ }^{12} \mathrm{C}$, or ${ }^{34} \mathrm{~S} /{ }^{32} \mathrm{~S}$.

Field triplicate samples for grass shrimp had standard deviations of generally less than $0.5 \%$ for $\delta^{13} \mathrm{C}, \delta^{15} \mathrm{~N}$, and $\delta^{34} \mathrm{~S}$

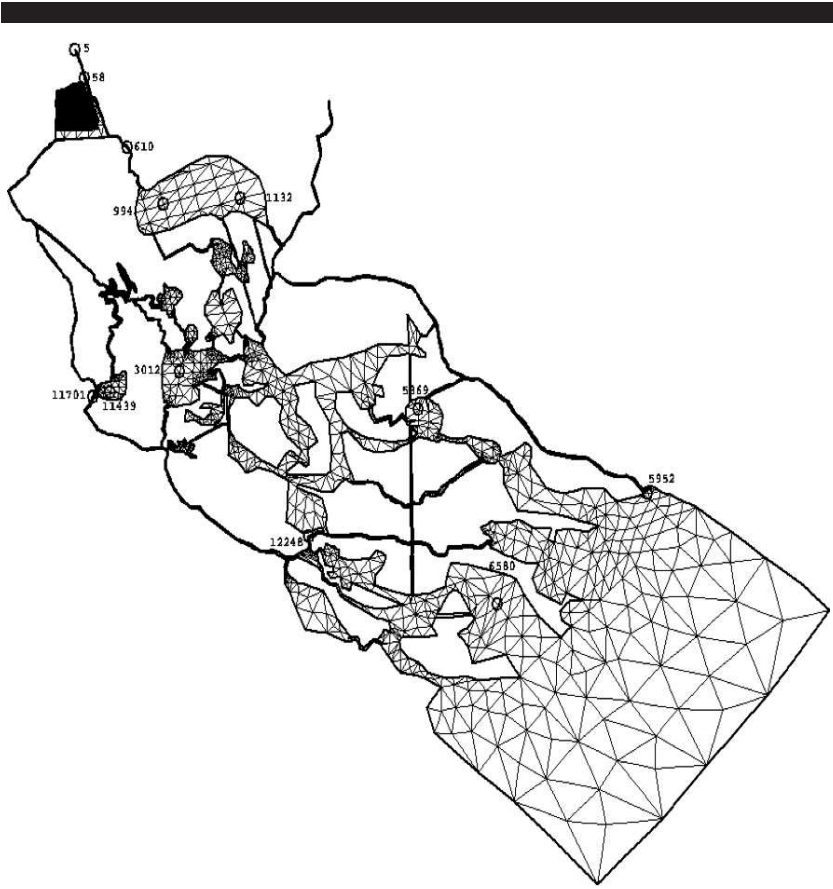

Figure 3. The TABS model grid of the open water area of the Breton Sound estuary.

values. Samples that were split in the laboratory and analyzed as laboratory duplicates (grass shrimp, barnacles, and bay anchovies) usually gave isotopic compositions that agreed within a $0.5 \%$ range for $\delta^{13} \mathrm{C}, \delta^{15} \mathrm{~N}$, and $\delta^{34} \mathrm{~S}$ values.

\section{Modeling}

A simulation model of the Caernarvon freshwater diversion was developed based on the TABS-MD numerical modeling system (Barrett, 1996; Capps and Willson, 2002; Freeman, 1992; Roig, 1994; Thomas and McAnally, 1990). The TABSMD includes separate hydrodynamic (RMA2), water quality (RMA4), and sediment transport modules (SED2D) that are generally run in sequence with the surface-water modeling system (SMS) software (EMRL, 2002). The SMS software provides valuable tools for mesh generation, data interpolation, and graphical visualization.

A finite element model grid of the Caernarvon-Breton Sound area (Figure 3) was developed using the SMS 8.0 software package. The SMS map module was used to import a satellite image acquired in 2000 to delineate model boundaries and major water features. Detailed features of the Breton Sound were added from 1-m resolution color infrared aerial photographs collected by the U.S. Geological Survey (USGS) during 1998. Configuration of channels and bank breaks were determined from surveys carried out during the reconnaissance phase. The built-in interpolation command in the mesh creator module of SMS was used to assign a depth for each individual node. Subsequently, hand editing was done to fine tune the topography and bathymetry in the model as additional data became available.

The TABS-MD model was coupled to a simple water quality 


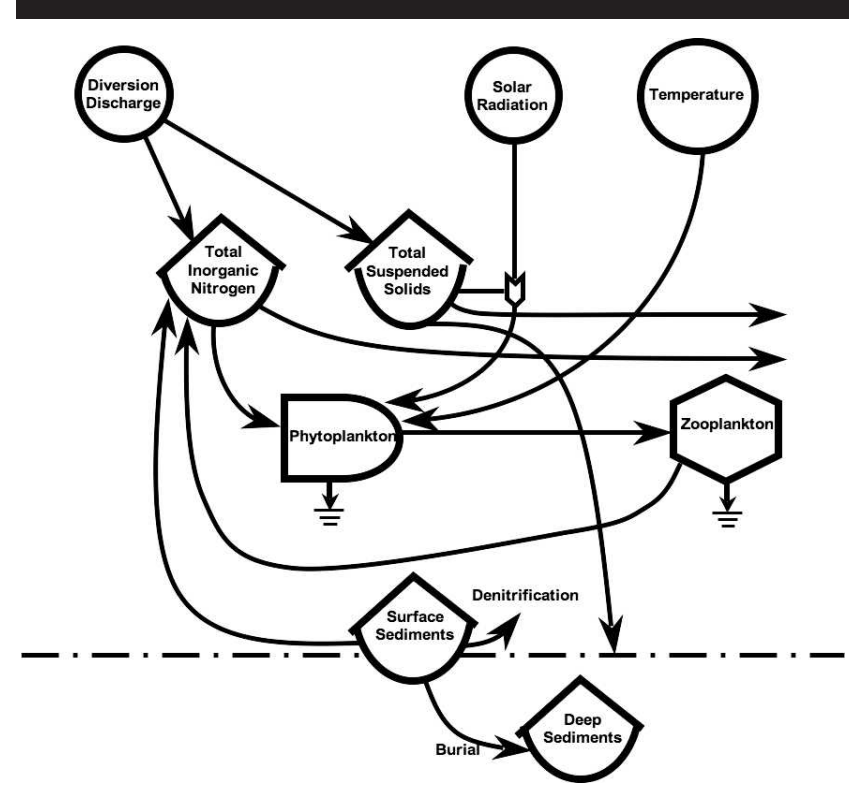

Figure 4. Diagrammatic representation of nitrogen-phytoplankton-zooplankton interactions in the model of the Breton Sound estuary.

model of the upper Breton Sound estuary (Figure 4). The water quality model includes elementary dissolved inorganic nitrogen (DIN) dynamics, algal nutrient uptake of the Monod type, and a single algal assemblage whose productivity is simultaneously limited by DIN availability, ambient light intensity, and zooplankton grazing. The coupled hydrodynamic-water quality model was calibrated using data collected from December 2001 through March 2002.

In a series of simulation experiments, we examined the residence times in the Breton Sound estuary and their impact on phytoplankton biomass accumulation. A simulated tracer (100 ppt) was released at the Caernarvon diversion site over a period of 48 hours, and tracer response curves were constructed for various sections of the estuary. From these tracer response curves, we calculated the $75 \%$ tracer removal time ( $=75 \%$ water residence time), i.e., the difference in time between the occurrence of the peak tracer concentration and the time when only $25 \%$ of the peak tracer concentration is retained in the system.

\section{RESULTS AND DISCUSSION}

\section{Freshwater Inputs, Residence Times, and Overland Flow}

The Caernarvon diversion was operated in "pulsed" events intended to mimic natural Mississippi River overbank flooding, but under controlled conditions. These pulses were approximately 14 days in length and introduced $4.5 \times 10^{8} \mathrm{~m}^{3}$ of river water into the Breton Sound estuary per event (Swenson et al., 2006). The upper estuary (volume: $2.0 \times$ $10^{8} \mathrm{~m}^{3}$ ) was replaced 2.25 times per event. Annually, the whole estuary volume $\left(9.0 \times 10^{8} \mathrm{~m}^{3}\right)$ was replaced 1.2 times and the upper basin volume was replaced 5.67 times. Thus, nearly half the annual water turnover in the upper estuary

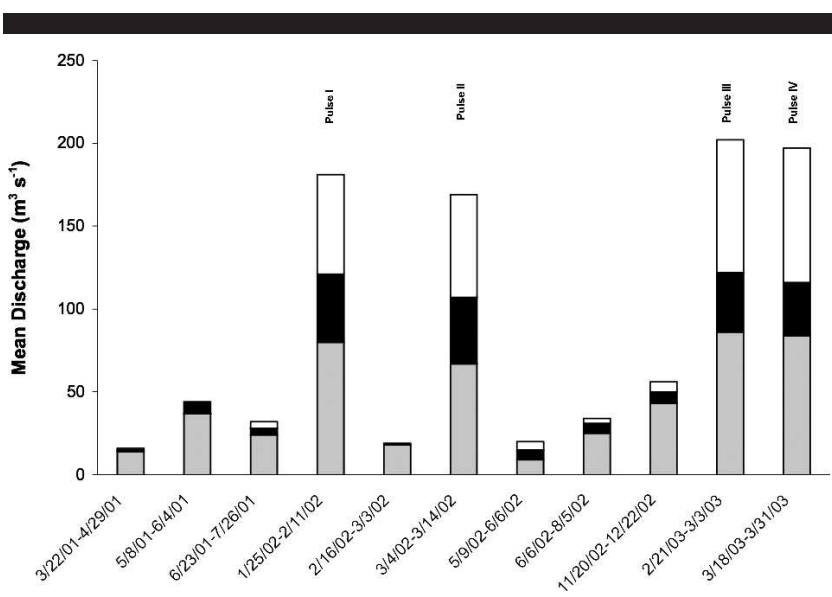

Figure 5. Discharge through the Caernarvon structure during 20012003. Gray bars are flow to the east via Bayou Mandeville, and black bars are flow to the west via Delacroix Canal. White bars are residual flow and is assumed to be over the marsh. High bars are experimental pulses.

occurred during the combined springtime experimental pulses of 4 weeks. This diverted river water decreases estuarine water replacement times, decreases the impact of drought years on the marshes, and enhances the export of water to the Gulf of Mexico. Annual freshwater export from the estuary to the Gulf of Mexico ranged from $35 \%$ to $56 \%$ of the total freshwater inputs (Hyfield et al., 2008).

Water level variations and circulation in the upper estuarine basin respond directly to the diverted river water, especially during high discharge pulses (Figure 5). When diversion discharge is less than $100 \mathrm{~m}^{3} \mathrm{~s}^{-1}$, the eastern and western routes typically convey roughly $80 \%$ and $15 \%$, respectively, of the diversion flows down estuary as channelized flow. Up to $5 \%$ of the flow may flow gulfward as sheet flow through the marsh, and this sheet flow generally occurs at low diversion discharge only when winds are blowing out of the south or east. Overmarsh sheet flow becomes more prevalent, routing nearly $40 \%$ of diversion flows down estuary, when diversion discharges exceed $100 \mathrm{~m}^{3} \mathrm{~s}^{-1}$. This over-marsh flow first fills marsh depressions and then uniformly raises interior marsh stages above the marsh surface. A $30-40 \mathrm{~cm}$ water level increase occurs in marshes of the upper estuary when discharges are greater than $200 \mathrm{~m}^{3} \mathrm{~s}^{-1}$ (i.e., 0.15 to $0.20 \mathrm{~cm}$ response per $\mathrm{m}^{3} \mathrm{~s}^{-1}$ of diverted water; Snedden, Cable, and Wiseman, 2007). In the upper estuary, over-marsh sheet flow velocities in response to the diverted river water ranges from 1.5 to $5 \mathrm{~cm} \mathrm{~s}^{-1}$, and flow direction is always to the south, away from the diversion structure (Snedden, 2006). During high diversion discharge, the remaining diversion inflows are routed to the Gulf of Mexico via the east (40\%) and west (20\%) routes as channelized flow.

\section{Suspended Sediment Delivery}

The diversion is the primary sediment source to the upper estuary, even though sediments also enter the lower estuary where the levees end and the Mississippi River flows into the estuary (Figure 1). Snedden et al. (2007) found for two 
Table 1. The relationship between average TSS concentration in the Mississippi River and total amount of sediment delivered is compared for two pulsed events. The first experimental pulse (1) was during a rising river discharge, and the second (pulse 2) was during a falling stage.

\begin{tabular}{|c|c|c|c|c|c|c|c|}
\hline Event & Date & $\begin{array}{l}\text { Average Diversion } \\
\text { Discharge }\left(\mathrm{m}^{3} \mathrm{~s}^{-1}\right)\end{array}$ & $\begin{array}{l}\text { Duration } \\
\text { (d) }\end{array}$ & $\begin{array}{l}\text { Average River Discharge } \\
\qquad\left(\mathrm{m}^{3} \mathrm{~s}^{-1}\right)\end{array}$ & $\begin{array}{l}\text { Average TSS } \\
\quad\left(\mathrm{mg} \mathrm{L}^{-1}\right)\end{array}$ & $\begin{array}{c}\text { Total Sediment } \\
\text { Delivery (tonnes) }\end{array}$ & tonnes $\mathrm{d}^{-1}$ \\
\hline Pulse 1 & 18 Feb-03 Mar 2003 & 195 & 13 & $1.97 \times 10^{4}$ & 197 & $4.38 \times 10^{4}$ & $3.29 \times 10^{3}$ \\
\hline Pulse 2 & 17 Mar-31 Mar 2003 & 193 & 15 & $2.01 \times 10^{4}$ & 101 & $2.46 \times 10^{4}$ & $1.64 \times 10^{3}$ \\
\hline Mean & & 194 & 14 & $1.99 \times 10^{4}$ & 149 & $3.42 \times 10^{4}$ & $2.47 \times 10^{3}$ \\
\hline
\end{tabular}

separate spring 2003 pulse events of approximately equal volumes of diverted river water $\left(\sim 20,000 \mathrm{~m}^{3}\right)$ that the sediment discharge rates of the first event $\left(3.29 \times 10^{3} \mathrm{t} \mathrm{d}^{-1}\right)$ were nearly twice that of the second event $\left(1.64 \times 10^{3} \mathrm{t} \mathrm{d}^{-1}\right.$; Table 1). The first event occurred on a rising river, which had a higher suspended sediment concentration $\left(197 \mathrm{mg} \mathrm{L}^{-1}\right)$ compared with the second event, which occurred as the river fell and had a lower sediment concentration $\left(101 \mathrm{mg} \mathrm{L}^{-1}\right)$. Snedden et al. (2007) found that a hysteresis effect occurred with respect to sediment load and river discharge, which clearly indicated the river sediment load was reduced on falling stage and higher on rising and cresting river stage. Thus, timing discharge of diverted river water to the estuary relative to the river hydrograph can be used to maximize sediment delivery to the estuary and marshes.

Once river-derived sediment enters the basin through the diversion, sediment transport is distributed in the estuary primarily down the two main flow routes until water levels are high enough to reach the marsh surface. A sediment mass balance reveals that about $10 \%$ to $20 \%$ of total sediment load likely reaches marsh surfaces in the upper estuary; $40 \%$ of the sediment is captured in Big Mar; 25\% flows into Bayou Mandeville; $11 \%$ is transported via Delacroix Canal; and $24 \%$ reaches the south end of Big Mar. Based on this mass balance and independent field observations (e.g., wetlands are now present where once open water appeared), it is likely Big Mar is filling in with river sediments and newly produced organic matter.

Sediment deposition on the marsh surface results from a complex set of conditions in which prevailing winds, water velocity, water levels, tides, river flow, and suspended sediment loads all contribute to marsh surface delivery. Wind-induced resuspension and transport of sediments stored in channels, lakes (i.e., Big Mar and Lake Leary), and ponds are major processes in the delivery of sediment to the marsh surface as well as the transport of diverted river sediment further south into the estuary (e.g., Perez et al., 2000). Statistical analysis revealed that deposition in Breton Sound estuary varies by season and decreases with distance from the diversion and proximity to a major waterway. Decreased deposition with increased distance from the sediment source is consistent with results reported for North Carolina (Leonard, 1997) as well as Louisiana marshes (Reed, 1992).

Short-term (weekly) sediment deposition as measured by sediment traps was equivalent to about $2.3 \mathrm{~cm} \mathrm{y}^{-1}$, while long-term accretion based on excess ${ }^{210} \mathrm{~Pb}$ geochronology in upper Breton Sound estuary revealed a much slower rate of 0.26 to $0.30 \mathrm{~cm} \mathrm{y}^{-1}$ (Wheelock, 2003). Short-term (pulsed event) deposition on marsh surfaces follows expected spatial trends (Figure 6), with its greatest event-driven deposition occurring close to the head of the estuary $(<6 \mathrm{~km})$ and closest to the edge of the channels. Sediment deposition is dominated by mineral inputs near the diversion but become more organic down basin (>10 km; Wheelock, 2003). Measurements of wetland surface elevation change and vertical accretion, for moderate time scale deposition (months to years), indicated substantial rates of accretion and elevation gain at all sites. The change in wetland surface elevation was always positive and ranged from $0.16 \pm 0.31$ to $0.42 \pm 0.21 \mathrm{~cm} \mathrm{y}^{-1}$; vertical accretion was between $0.75 \pm 0.04$ and $1.57 \pm 0.05 \mathrm{~cm} \mathrm{y}^{-1}$; and shallow subsidence ranged from 0.59 to $1.21 \mathrm{~cm} \mathrm{y}^{-1}$. Long-term (decadal scale) deposition is low, and likely reflects the decomposition of buried organic matter as well as compaction and compression of sediments. The long-term estimates of deposition were consistent with the sediment elevation table measurements. These sediment deposition data illustrate some important points about the marsh deposition. Short-term sediment trap measurements capture net deposition that includes resuspended particles and provide a useful tool for identifying hotspots of deposition because many more samples can be collected over a short period. However, the sediment trap deposition rates are only indicative of recent transport events and cannot capture the effects of burial, diagenesis, or below ground organic accumulation. The long term measurement techniques (i.e., sediment elevation tables and ${ }^{210} \mathrm{~Pb}$ dating) are much more effective at estimating marsh sustainability. Analysis of regional relative sea-level rise (RSLR) compared with

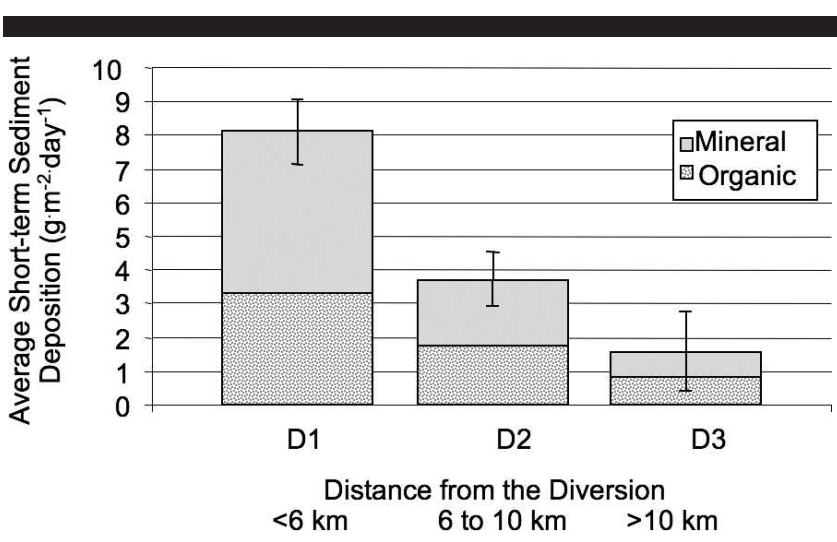

Figure 6. Short-term sediment trap results for the upper Breton Sound estuary show a strong correspondence between deposition and distance from the diversion (Wheelock, 2003). Sediment deposition was partitioned into the organic component derived from plant and algal detritus in the marshes and the mineral component derived directly from the Mississippi River. 


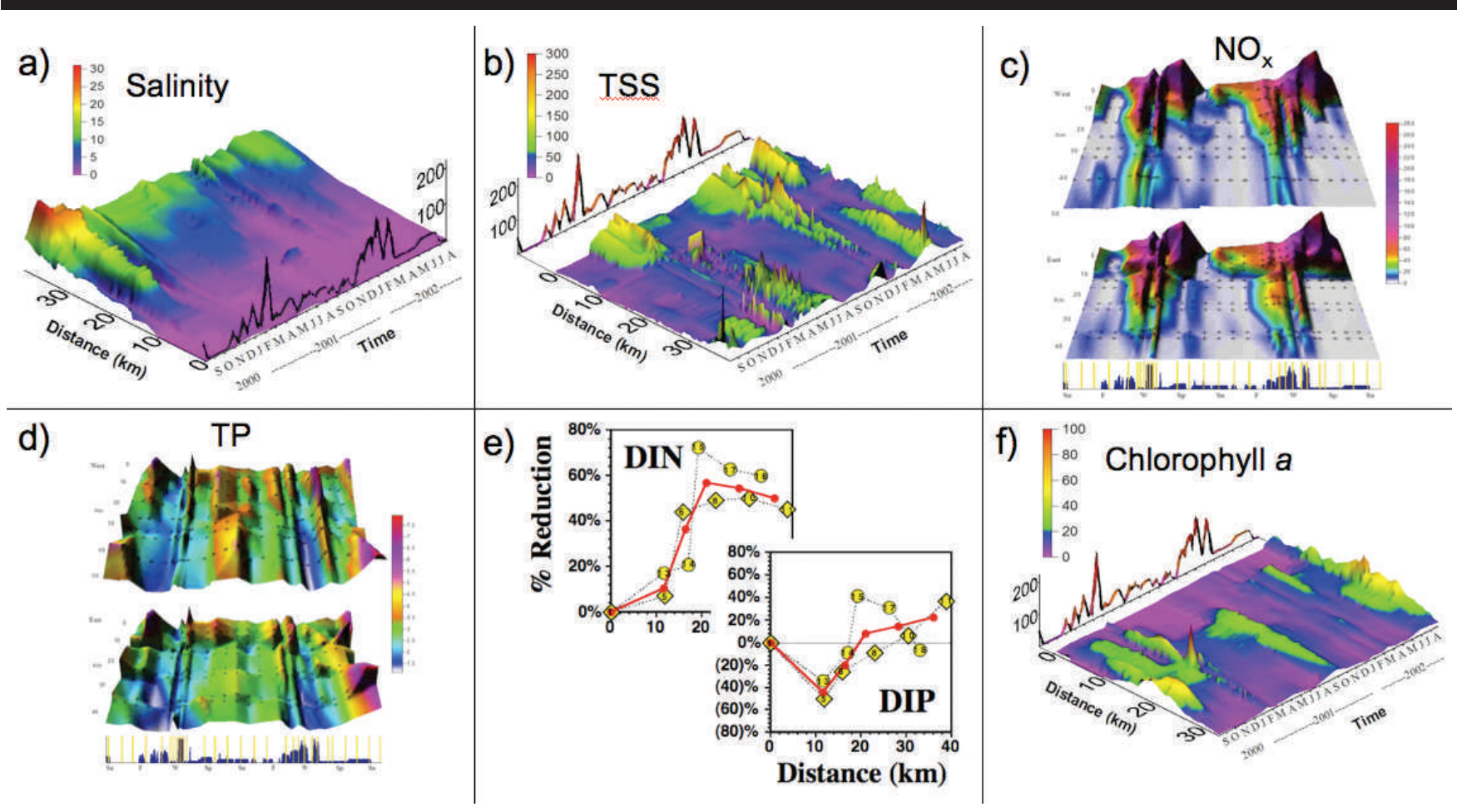

Figure 7. Selected water quality data from the flow-through transects are provided for Breton Sound estuary (from Lane et al., 2007).

sediment elevation data indicated all Caernarvon sites are keeping pace with RSLR (Lane, Day, and Day, 2006).

\section{Synoptic Nutrient and Hydrographic Patterns}

Flow-through transects showed strong seasonal and spatial patterns in nutrient concentration and hydrographic parameters (Lane et al., 1999, 2004, 2007). Strong seasonal temperature signals were found in the estuary, with summer highs of $>30^{\circ} \mathrm{C}$ and winter lows of $<12^{\circ} \mathrm{C}$. Incoming river water was usually cooler than estuarine waters, with temperatures as low as $6^{\circ} \mathrm{C}$, but generally equilibrated with the ambient temperature in the rest of the estuary within several kilometers of the diversion. Salinity in the upper estuary was fresh throughout the study, and increased down estuary up to 14 and 30 psu along western and eastern routes, respectively (Figure 7a). Discharge from the river diversion greatly affected salinity, with the large spring pulses often causing the entire estuary to become fresh for short periods of time ( $<1$ month). A temporal lag of about 2 weeks between discharge and minimum salinity in the lower estuary occurred in 2001.

Mississippi River water entered the estuary with TSS concentrations ranging from 40 to $252 \mathrm{mg} \mathrm{L}^{-1}$ and an average of $118 \mathrm{mg} \mathrm{L}^{-1}$ (Figure $7 \mathrm{~b}$ ). Sediment from the river diversion was often carried about 10 to $15 \mathrm{~km}$ down the estuary during spring pulses, but sediment was observed to exit the estuary along Bayou Terre aux Boeufs in 2001 (Walker et al., 2003). At the mouth of the estuary, highly fluctuating TSS concentrations were observed during winter and spring, which was attributed to wind resuspension during frontal passages. These frontal passages tend to arrive about every 4 to 10 days along the Louisiana coast (Perez et al., 2000).

Nitrogen behavior was much more dynamic than other nutrients. Nitrate + nitrite $\left(\mathrm{NO}_{x}\right)$ comprised $>90 \%$ of dissolved inorganic nitrogen (DIN) input from the diversion, with large fluxes into the basin during late winter-early spring associated with high discharge (Figure 7c). Consistent decreases in $\mathrm{NO} x$ concentrations occurred along both the east and west routes, indicating $\mathrm{NO}_{x}$ was strongly nonconservative and the estuary was a sink for $\mathrm{NO}_{x}$. There was low loading $\left(<10 \mathrm{~g} \mathrm{~N} \mathrm{~m}^{-2} \mathrm{y}^{-1}\right)$, and potential for high DIN uptake (Hyfield et al., 2008; Lane et al., 2004). Ammonium $\left(\mathrm{NH}_{4}\right)$ concentrations fluctuated between 2.5 and $5.0 \mu \mathrm{M}$, with negligible concentrations during periods of high $\mathrm{NO}_{x}$, and high concentrations during periods of low $\mathrm{NO}_{x}$, suggesting regeneration as a source of $\mathrm{NH}_{4}$ throughout the basin. Trends in the total nitrogen (TN) concentrations within the basin resembled $\mathrm{NO}_{x}$. TN concentrations increased during the late winter and early spring, ranging from 100 to $280 \mu \mathrm{M}$, associated with increased input from the river diversion. Concentrations decreased with increasing distance from the diversion structure. During the summer-fall period, values in the middle and lower estuary were consistently $<70 \mu \mathrm{M}$.

Phosphate $\left(\mathrm{PO}_{4}\right)$ concentrations during late spring-early summer were typically $>1.5 \mu \mathrm{M}$, with increasing values toward the diversion and at the marine end of the estuary. Lower $\mathrm{PO}_{4}$ values occurred during late winter and early spring. However, distinct zones of high $\mathrm{PO}_{4}$ concentrations were evident during periods of high discharge during the 
winter. Total phosphorus concentrations were higher during the warmer summer months $(>3 \mu \mathrm{M})$, and lower during the colder winter months $(<2 \mu \mathrm{M}$; Figure $7 \mathrm{~d})$. Total phosphorus was also higher during periods of high river diversion discharge. By comparison, silicate concentrations were higher in the upper and lower basin during the summer $(>110 \mu \mathrm{M})$, and in the midestuary concentrations typically ranged from 70 to $100 \mu \mathrm{M}$. Low concentrations occurred during the winter and early spring within the lower estuary $(<45 \mu \mathrm{M})$. Silicate levels were higher during the winter in periods of high diversion discharge. In the upper basin, silicate concentrations were $>80 \mu \mathrm{M}$, regardless of season.

Significant changes in nutrient concentrations and in stoichiometric nutrient ratios were observed as diverted river water passed through the estuary (Lane et al., 2004). Rapid, nonconservative nutrient reductions occurred in the first $20 \mathrm{~km}$ of the study area of up to $44 \%$ for TN, $62 \%$ for TP, $57 \%$ for DIN, $23 \%$ for DIP, and $38 \%$ for DSi (Figure 7e). TN, TP, DIN, DIP, and DSi concentrations in the river were 137 to $140,5.0$ to $5.1,104$ to $153,1.1$ to 1.3 , and 114 to $121 \mu \mathrm{M}$, respectively, and 36 to $122,1.8$ to $3.6,13$ to $119,0.3$ to 1.8 and 29 to $110 \mu \mathrm{M}$, respectively, at the Gulf end member stations. The DSi : DIN ratio rose from 0.9 at the Caernarvon diversion to 2.6 at the Gulf end member station, while the DIN : DIP ratio fell from 107 to 26 . These results indicate river diversions can significantly reduce the overall nitrogen loading and alter the stoichiometric ratios at which dissolved nutrients are delivered to the Gulf of Mexico.

Chlorophyll $a(\mathrm{Chl} a)$ concentrations were highest in midestuary during summer and fall when discharge was low, and lowest during winter and spring with high discharge (Figure 7f). Chlorophyll a levels were generally less than $10 \mu \mathrm{g} \mathrm{L}^{-1}$ in the upper estuary, with concentrations rising in the midestuary generally to $20-30 \mu \mathrm{g} \mathrm{L}^{-1}$ during late summer and fall, and decreasing in the lower estuary. Several periods of less than a month during late summer and early winter were present when high $\mathrm{Chl} a$ concentrations were measured, ranging from 38 to $>60 \mu \mathrm{g} \mathrm{L} \mathrm{L}^{-1}$. This spike in Chl $a$ was most likely caused by interactions among water residence time, turbidity, nutrients, and temperature. As indicated by the salinity data and modeling results, water residence time was reduced during high riverine discharge, leading to increased flushing of phytoplankton biomass out of the estuary, as well as increased turbidity. Conversely, as riverine discharge decreased during summer, turbidity decreased and water residence time increased, allowing the buildup of phytoplankton biomass and leading to increased Chl $a$ concentrations. This increased biomass was most likely supported by an increase in benthic regeneration of nutrients associated with higher summer water temperatures (Day, Kemp, and YáñezArancibia, 1989; Kemp and Boynton, 1984). This is corroborated by observed increases in ammonium and phosphate concentrations in the estuary during the summer and high summer nutrient remineralization (Baker, 2005). Such decoupling between riverine nutrient input during spring and peak phytoplankton productivity during summer has been observed in many other estuaries (Boynton, Kemp, and Keefe, 1982; Fisher, Harding, and Stanley, 1988; Madden, Day, and Randall, 1988; Nixon, 1981).

\section{Marsh Sediment-Water Column Interactions}

Flow of diverted river water over the marsh affects temperature and nutrient concentrations. In comparing results from the north flume (near the diversion) to the south flume (far from the diversion) a number of changes occurred with respect to nutrient concentrations. In the southern flume, temperature was $5^{\circ} \mathrm{C}$ to $7^{\circ} \mathrm{C}$ higher and water levels were about $10 \mathrm{~cm}$ lower (relative to marsh surface) than in the northern flume. Turbidity (NTU) was generally 20-30 in the northern flume and zero in the southern flume, and current velocities were about $7 \mathrm{~cm} \mathrm{~s}^{-1}$ in the northern flume compared with about $1 \mathrm{~cm} \mathrm{~s}^{-1}$ in the southern flume. Velocity near the marsh sediment surface was near zero.

Concentrations of $\mathrm{NO}_{3}$ entering the upper flume were 60 $80 \mu \mathrm{M}$ (already lower than river water) and there was no $\mathrm{NO}_{3}$ uptake in the flume, likely due to low temperatures and short residence time of water in the flume $(<1$ hour) and high loading rates $\left(>30 \mathrm{~g} \mathrm{~N} \mathrm{~m}^{-2} \mathrm{y}^{-1}\right)$. This suggests that longer flumes are necessary in the upper area. Water entering the lower flume had no measurable $\mathrm{NO}_{3}$. This suggests that $\mathrm{NO}_{3}$ uptake occurred between the two flumes. The increase in temperature as water flowed over the marshes enhanced $\mathrm{NO}_{3}$ uptake. At temperatures greater than $10^{\circ} \mathrm{C}$, there was high $\mathrm{N}_{2}$ production, reflecting increased denitrification. At higher temperatures, there were high denitrification rates $(\sim 250$ $300 \mu \mathrm{mol} \mathrm{m}{ }^{-2} \mathrm{~h}^{-1}$, while at temperatures lower than $10^{\circ} \mathrm{C}$, rates were very low. At temperatures greater than $10^{\circ} \mathrm{C}$, there was a good relationship between temperature and DIN concentration and uptake (Baker, 2005). The highest potential for uptake was in Spanish Lake (Baker, 2005). Silicate fluxes were into the wetlands, indicating uptake by the benthic community.

\section{Water and Nutrient Budgets}

Diverted river water was a major source of freshwater and nutrients to the Breton Sound estuary during the study period (Hyfield et al., 2008). Precipitation was also a major freshwater contributor to the Breton Sound estuary, representing $48 \%$ to $57 \%$ of the freshwater budget, and its interannual variability has a strong effect on the basinwide water budget. However, precipitation (as atmospheric deposition) did not represent a strong source of nutrients. Precipitation was $1.05 \mathrm{~m}$ in 2000, $1.57 \mathrm{~m}$ in 2001, and $1.87 \mathrm{~m}$ in 2002, reflecting drought, relatively normal, and wet climate years. The Caernarvon diversion contributed $33 \%$ to $48 \%$ of all freshwater entering the estuary, and its contribution to the overall freshwater budget varied with respect to precipitation; i.e., more diverted river was needed to compensate for freshwater deficits during the drought and less river water was needed during the wetter year. Groundwater input was negligible, accounting for only $0.02 \%$ to $0.03 \%$ of total freshwater to the estuary. Stormwater pumps contributed $4 \%$ to $11 \%$ of freshwater input to the system. Overall, the average freshwater export from Breton Sound to the Gulf of Mexico was about $46 \%$ of the total freshwater inputs to the upper Breton Sound basin (Hyfield et al., 2008).

The diversion was the most important input source for 
DIN, TN, and TP to the estuary (Hyfield et al., 2008). Atmospheric input was the most important source for $\mathrm{NH}_{4}$, but $\mathrm{NH}_{4}$ input was less than $10 \%$ of total DIN input. Stormwater inputs were the greatest source of $\mathrm{PO}_{4}$, but better estimates are needed for nutrient concentrations in stormwater. The diversion supplied $67 \%$ to $83 \%$ of nitrate input to the estuary, while $10 \%$ to $17 \%$ was from atmospheric deposition, and the remainder came from stormwater pumps. The diversion supplied $60 \%$ to $71 \%$ of TN input, while $14 \%$ to $20 \%$ was from precipitation and $8 \%$ to $26 \%$ was from pumps. Wet atmospheric deposition was the largest contributor of $\mathrm{NH}_{4}-\mathrm{N}$ in the estuary, accounting for $57 \%$ to $62 \%$ of the total $\mathrm{NH}_{4}$ budget. The diversion contributed $12 \%$ to $31 \%$ of $\mathrm{NH}_{4}-\mathrm{N}$ inputs, and stormwater pumps accounted for $12 \%$ to $30 \%$. The diversion contributed $43 \%$ to $62 \%$ of TP input, but stormwater pump inputs supplied the majority of TP during the wet year of $2002\left(56 \% ; 2.51 \times 10^{5} \mathrm{~kg}\right)$. Precipitation accounted for only $7 \%$ to $13 \%$ of TP input.

Within the total study area, the maximum loading rates of $\mathrm{NH}_{4}-\mathrm{N}$ and $\mathrm{NO}_{3}-\mathrm{N}$ were 0.27 and $2.3 \mathrm{~g} \mathrm{~N} \mathrm{~m}^{-2} \mathrm{y}^{-1}$, respectively (Hyfield et al., 2008). Total nitrogen ranged from 2.1 to $3.5 \mathrm{~g} \mathrm{~N} \mathrm{~m}^{-2} \mathrm{y}^{-1}$ and TP ranged from 0.24 to $0.53 \mathrm{~g} \mathrm{P} \mathrm{m}^{-2} \mathrm{y}^{-1}$. Within the upper basin, TN and TP loading ranged from 4.8 to $8.0 \mathrm{~g} \mathrm{~N} \mathrm{~m}^{-2} \mathrm{y}^{-1}$ and 0.56 to $1.2 \mathrm{~g} \mathrm{P} \mathrm{m}^{-2} \mathrm{y}^{-1}$, respectively. $\mathrm{NO}_{3}$ loading ranged from 2.7 to $5.3 \mathrm{~g} \mathrm{~N} \mathrm{~m}^{-2} \mathrm{y}^{-1}$. The loading rate analysis showed that annual loadings for nitrogen and phosphorus were low compared with the range of values reported in the literature (e.g., Day et al., 2004; Mitsch and Gosselink, 2007; Mitsch et al., 2001, 2005; Richardson and Nichols, 1985). These low loading rates are corroborated by the high $\mathrm{N}$ and $\mathrm{P}$ removal rates reported by Lane et al. (2004).

\section{Phytoplankton Responses}

Over the study period, the phytoplankton community of Breton Sound estuary was mainly composed of diatoms, chlorophyceae, and cyanobacteria. Other frequently occurring groups, like dinoflagellates, cryptophyceae, chrysophyceae, and euglenophyceae, did not contribute major percentages of the phytoplankton biomass.

The structure of the phytoplankton community displayed a strong spatial, seasonal, and interannual variability in the estuary. Figure 8 depicts changes in phytoplankton community structure at three of the monthly surveyed stations located along a gradient of increasing distance from the diversion (diversion $0 \mathrm{~km}$, Lake Leary East $23 \mathrm{~km}$, Grand Lake $50 \mathrm{~km}$ ). Cyanobacterial abundance usually was highest in summer and fall when water temperatures were elevated. While cyanobacteria peaked in Lake Leary and Grand Lake in 2002, the stations closer to the diversion showed a maximum development of this group in 2003. Higher volumes of diverted river water led to flushing of phytoplankton, especially nearer to the diversion.

The results of principal components analysis (PCA) indicate $54.2 \%$ of the variability in community structure could be explained by the first three principal components (PC1$31.3 \%$, PC2-14.3\%, PC3-8.6\%). Thus, diatoms were most closely related to light conditions, second to concentrations of ammonium, and third to organic phosphorus, whereas wind

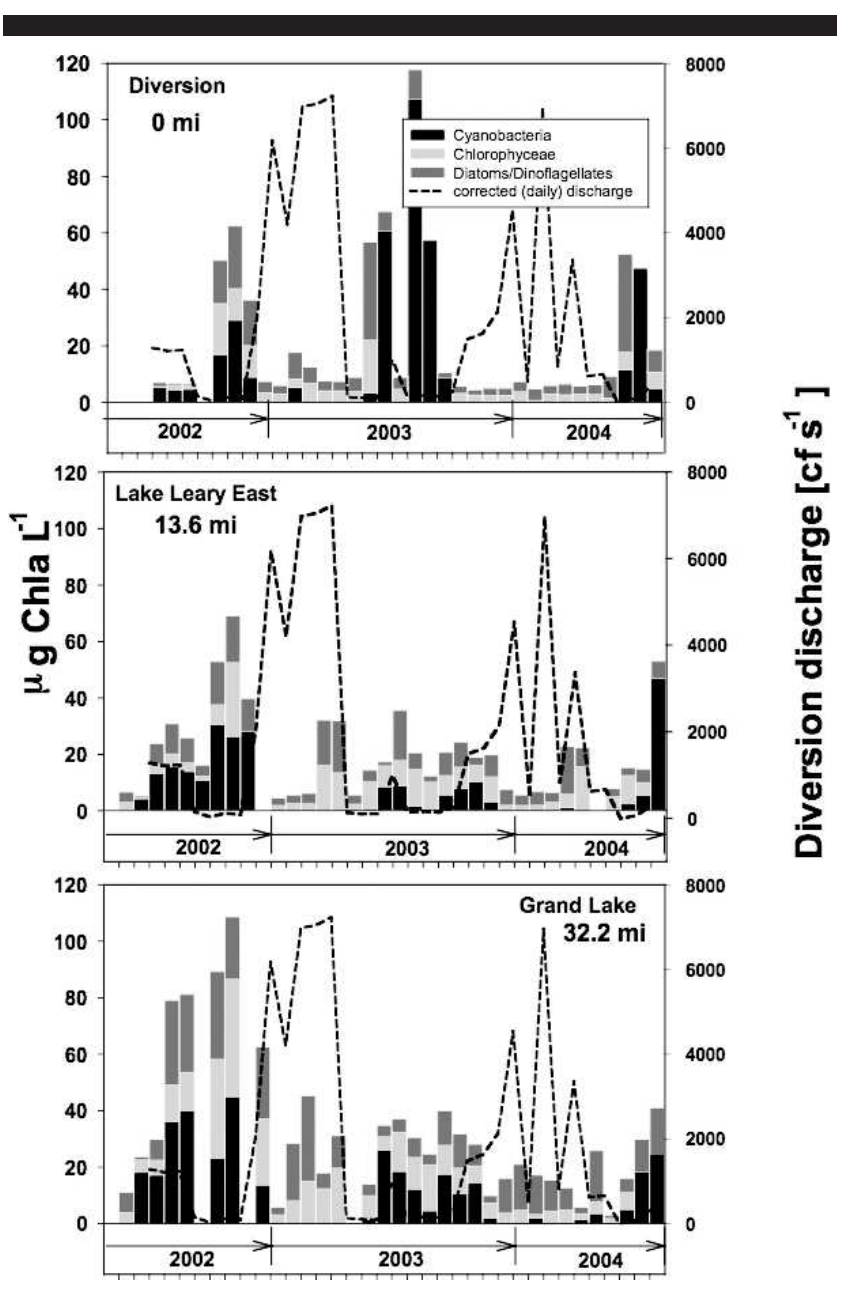

Figure 8. Spatial, seasonal, and interannual variability of the phytoplankton community structure are shown for three stations with increasing distance from the diversion (Breton Sound estuary, February 2002September 2004). Chlorophyll $a$ concentrations of the three major groups (cyanobacteria, chlorophyceae, and diatoms or dinoflagellates) are given as stacked bars for the monthly surveys along with diversion discharge (dashed line) averaged for 5 days prior to phytoplankton sampling.

speed had an important negative effect. Green algae showed the same pattern, with the slight difference that ammonium concentrations and light changing order of importance. Cyanobacterial chlorophyll was most closely related to organic phosphorous, secondly to light, and thirdly to temperature. Additional positive correlations existed with organic nitrogen and rainfall. Wind speed (1), diversion discharge (2), and $\mathrm{NO}_{x}$ concentrations (3) related negatively to cyanobacteria. All remaining vectors (soluble reactive phosphate [SRP], Si, salinity [PSU], and distance [DIST]) showed no relation to the cyanobacterial abundance.

Phytoplankton community composition influences nutrient processing in the water column (e.g., partly determines the amount of nitrogen that reaches the sediments as a result of settling). The process of phytoplankton nitrogen uptake and settling is likely one of the primary controls on the rate of sediment burial of nitrogen in diverted river waters and permanent loss of diverted nitrogen via the processes of 

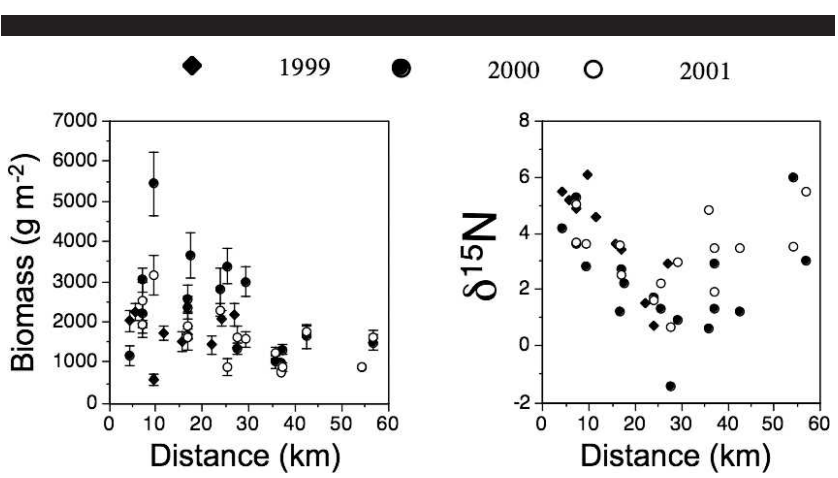

Figure 9. End of season live (EOSL) aboveground marsh biomass and $\mathrm{N}$-stable isotope of marsh vegetation.

denitrification or anaerobic ammonium oxidation (Twilley and Rivera-Monroy, 2009). Management efforts should promote diatom and green algal development, and minimize the potential for cyanobacterial blooms. As stated earlier, major factors influencing cyanobacterial development are phosphorus, light, temperature, and water column stability. Cyanobacteria prefer stable water column conditions while the other groups perform better if the water column is mixed. Thus diverted water is likely to flush out cyanobacteria.

\section{Aboveground Marsh Biomass}

End of season peak live (EOSL) aboveground biomass ranged from 587 to $5434 \mathrm{~g}$ dry wt $\mathrm{m}^{-2}$ (Figure 9). Species composition ranged from freshwater species such as Panicum virgatum, Polygonum sp., and Alternanthera philoxeroides near the diversion to saltwater species, dominated by Spartina patens and $S$. alterniflora, in higher salinity waters near Breton Sound. ESOL biomass was highly variable, but the highest values $\left(>2000 \mathrm{~g} \mathrm{~m}^{-2}\right)$ were found within $20 \mathrm{~km}$ of the diversion. Beyond $40 \mathrm{~km}$ from the diversion, values were lower than $2000 \mathrm{~g} \mathrm{~m}^{-2}$. Plants collected inside the Mississippi River levees affected by water in the river had $\delta^{15} \mathrm{~N}$ values that ranged from $8.5 \%$ to $9.9 \%$, with a mean of $9.0 \%$, which corresponds with a previous study that reported Mississippi River sediments had $\delta^{15} \mathrm{~N}$ values of approximately 9\%o (Mayer et al., 1998). The marsh without riverine input had a mean $\delta^{15} \mathrm{~N}$ of $2.6 \%$. $\delta^{15} \mathrm{~N}$ of plants in the Breton Sound estuary ranged from $6.1 \%$ to $0.7 \%$, with values decreasing with distance until midestuary $(25-35 \mathrm{~km})$, after which values steadily increased (Figure 10), most likely due to river water entering the estuary from the Gulf of Mexico (Lane, Day, and Thibodeaux, 1999). Minimum $\delta^{15} \mathrm{~N}$ in EOSL biomass and POM both indicated the lowest riverine influence in midestuary.

Recently, studies have shown that adding nutrients reduced belowground productivity, suggesting that excess nutrient loading can make marshes more susceptible to hurricane damage. These studies used nitrogen loading rates of $200 \mathrm{~g} \mathrm{~N} \mathrm{~m}^{-2} \mathrm{y}^{-1}$ or higher (Darby and Turner, 2008a, 2008b). Loading rates at Caernarvon are far less than those used in these studies, with the upper basin having $\mathrm{NO}_{3}$ and TN loading ranging from 2.7 to $5.3 \mathrm{~g} \mathrm{~N} \mathrm{~m}^{-2} \mathrm{y}^{-1}$ and 4.8 to
$8.0 \mathrm{~g} \mathrm{~N} \mathrm{~m}^{-2} \mathrm{y}^{-1}$, respectively (Hyfield et al., 2008). And nutrient loading rates from the Atchafalaya River to the marshes surrounding Fourleague Bay are less than $10 \mathrm{~g} \mathrm{~N}$ $\mathrm{m}^{-2} \mathrm{y}^{-1}$ (Lane et al., 2002). Wetland loss in the region affected by the Atchafalaya River are generally low (Britsch and Dunbar, 1993), and salt marshes southeast of Fourleague Bay are well-drained, have high soil strength, and have remained stable over the past several decades (Day et al., 2009). Recently, Day et al. (2009) reported high belowground biomass in marshes affected by the Caernarvon diversion. Thus, while high nutrient loading to coastal marshes remains an issue, the data suggest that this is not a problem at Caernarvon. Swarzenski et al. (2008) suggested that chronic riverine input led to deterioration of soils in highly organic freshwater marshes. This should be monitored in current and future diversions.

\section{Estuarine Consumers and Food Webs}

The Barataria Basin, which serves as an analogue to Breton Sound Basin because of its proximity to the river and similar geomorphology, also offers a unique contrast because it received very little river water input during our study. In the Barataria Basin we observed typical estuarine gradients with $\mathrm{PO}^{13} \mathrm{C}$ (particulate organic carbon) values ranging from $-30 \%$ in freshwater areas to $-22 \%$ oward the marine end, and $\mathrm{PO}^{15} \mathrm{~N}$ (particulate organic nitrogen) values were generally below 6\% (Wissel, Gace, and Fry, 2005). In contrast, in upper Breton Sound $\mathrm{PO}^{13} \mathrm{C}$ and $\mathrm{PO}^{15} \mathrm{~N}$ were highly elevated, reflecting values commonly found in the Mississippi River (Figure 10). Additionally, a secondary influence of the Mississippi River occurs at the marine ends of both estuaries where major natural discharge from the Bird's Foot Delta wraps around into estuarine waters. In general, low $\mathrm{C}: \mathrm{N}$ ratios and regionally high $\mathrm{POM}$ concentrations indicated the importance of phytoplankton in both areas. A mixing model based on $\mathrm{C}: \mathrm{N}$ and $\mathrm{PO}^{13} \mathrm{C}$ values estimated $80 \%$ of $\mathrm{POC}$ in Breton Sound was derived from algal carbon, while in the Barataria Basin estuary the algal contribution was lower at about $70 \%$ (Eldridge and Cifuentes 2001). Surprisingly, Spartina detritus was not a significant source to POC in either estuary. The seasonality of algal blooms in Breton Sound was driven by the diversion discharge schedule because blooms occurred approximately 3 to 4 months after the river stage decreased and the diversion discharge stopped, and no temporal correspondence was detected with the neighboring Barataria estuary.

Mixing models for estuarine consumers showed that the river diversion was directly associated with two of the five major source regimes identified to support local food webs: a river regime near the diversion and a river-influenced productive (fertilized) marsh regime farther away from the diversion along the eastern side of the estuary (Wissel and Fry, 2005). Analogous to phytoplankton, we identified a third river-influenced source regime at the marine end of the estuary where Mississippi River water from the Bird's Foot Delta reaches the estuary. The remaining two source regimes represented typical estuarine conditions, local freshwater sources from precipitation and a brackish source regime 

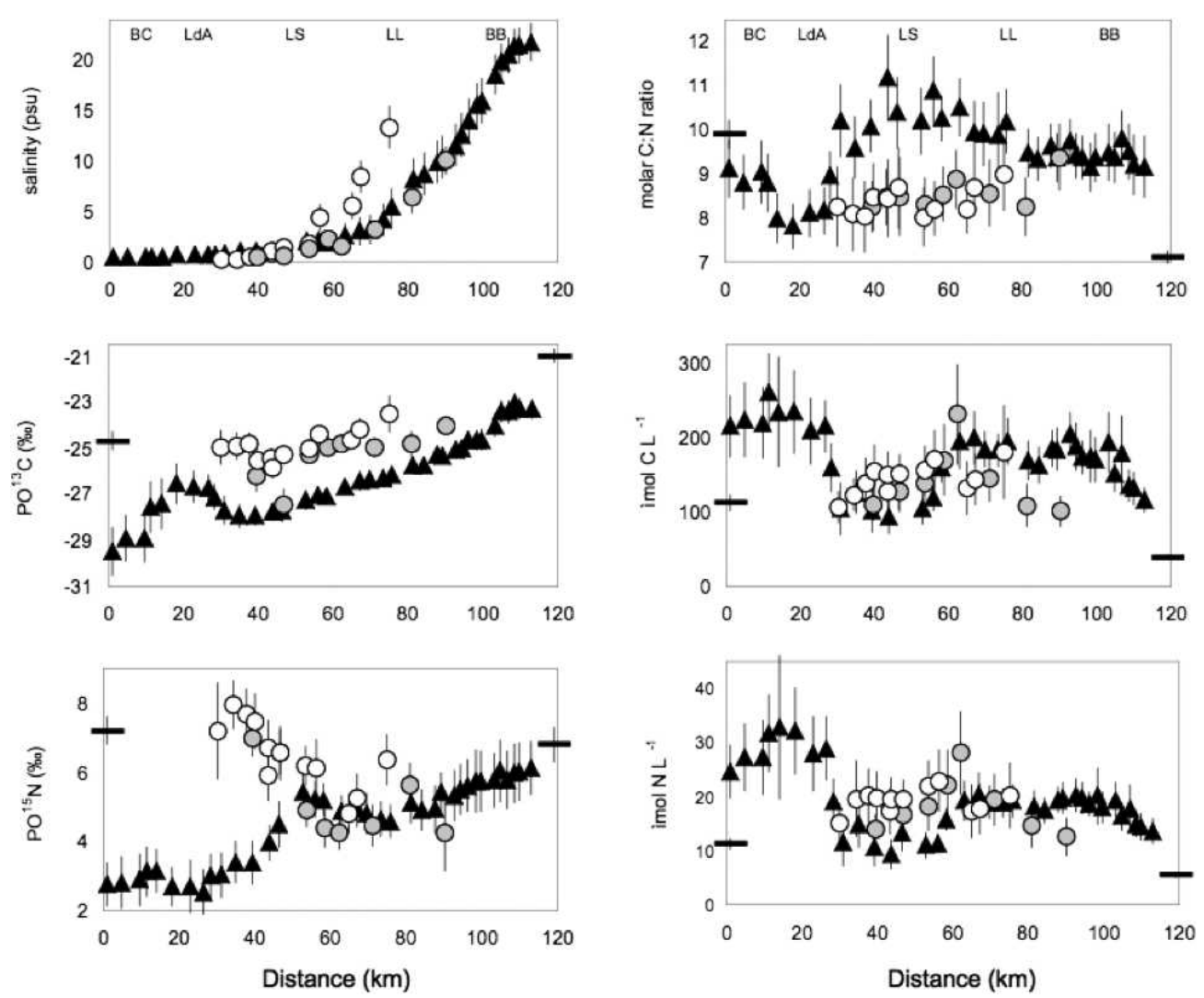

Figure 10. Average salinity and POM values in Barataria Basin (closed triangles) and Breton Sound (circles) for 2 years, September 2000-September 2002 (Wissel, Gace, and Fry, 2005). Values are plotted as distance from the freshwater end of the estuary, with $30 \mathrm{~km}$ added to the Breton Sound distances. Average values for end-member Mississippi River and offshore waters are shown as horizontal bars on the left and right axes, respectively. Abbreviations at top refer to major water bodies in Barataria Bay. Mississippi River nutrient inputs are especially evident as higher $\delta^{15} \mathrm{~N}$ values at the upstream, neardiversion end of Breton Sound and at the mouth of Barataria Bay that is close to the river outlet at Southwest Pass (see lowest left panel, 30-km station for Breton Sound, 110-km station for Barataria Bay). POM in Breton Sound also has low C/N (see uppermost right panel), consistent with high phytoplankton standing stocks developing in response to nutrient loading from the Caernarvon diversion.

representing higher salinity marine influences. Overall, the Mississippi River diversion supported $75 \%$ and $25 \%$ of local benthic and pelagic food webs in the upper and middle parts of the estuary, respectively, with influence strongest along known flow pathways and closest to the diversion. Isotopes also traced seasonal changes in river contributions because river-associated sources were especially important during and shortly after high discharge periods. Yet, the riverinfluenced source regime at the marine end did not show seasonality related to the diversion. Furthermore, increased primary productivity could be inferred from elevated $\delta^{13} \mathrm{C}$ values that we measured along the major flow path of diversion water. This conclusion was further supported by significantly elevated coverage of submerged aquatic vegetation (SAV) in the inflow vs. reference area in the Breton Sound estuary $(p<0.00001)$. The coverage of SAV in Louisiana estuaries is inversely related to salinity (Chabreck, 1971), and by freshening estuarine waters, diversion inflows expand the area suitable for SAV. Average SAV coverage at sites affected by the diversion was $66 \%$ compared with $18 \%$ at reference sites that did not receive any diversion water (Rozas et al., 2005). In addition, daytime dissolved oxygen concentration was significantly higher at inflow $v s$. reference sites ( $p$ $<0.001$ ). This expansion of SAV is expected to benefit nekton (fishes and decapod crustaceans) unless SAV growth becomes excessive and reduces water quality (i.e., causes nighttime hypoxia) (Rozas et al., 2005). Isotope studies showed strong river-related labeling of all parts of the food web indicating pervasive bottom up incorporation of riverine nutrients. Riverine nutrients were also important for development of extensive SAV beds that altered faunal community structure in the diversion-impacted area (Rozas et al., 2005).

\section{Nekton Population Dynamics}

River diversions also can affect estuarine habitats, and thereby influence nekton populations, by changing habitat accessibility. During experimental pulses in February and March 2005, Piazza and La Peyre (2007) compared marsh flooding and nekton distribution patterns between the inflow area below the Caernarvon structure and a nearby reference area that did not receive freshwater from the diversion. 
Marsh flooding was twice as long in the inflow than in the reference area during these experimental pulses, and the density and biomass of the dominant freshwater species also were significantly higher in the inflow than reference marshes (Piazza and La Peyre, 2007). Using short-term field experiments, Piazza (2009) also showed that during these experimental pulses, growth rates of western mosquitofish (Gambusia affinis), a common marsh resident, were higher in the inflow than reference area.

Nekton populations also could be affected where diversions change marsh-water patterns by substantially reducing the amount of marsh-edge habitat in brackish and saline marsh vegetation zones (Minello, 1999; Minello and Rozas, 2002; Minello, Zimmerman, and Medina, 1994; Peterson and Turner 1994; Reed et al., 2007). Most sediment deposition from the Caernarvon diversion occurs in the upper estuary (Figure 6; Wheelock, 2003), and any significant change in marsh-water patterns caused by the diversion would likely occur in the fresh and intermediate marsh zones of the estuary where populations of most estuary-dependent species are in general relatively low. In fact Levinton (2001) describes the salinity range of 3 to 8 in estuaries as a critical transition zone in which diversity and abundance are low compared with both more and less saline reaches of the estuary. $\mathrm{He}$ attributes this observation to problems with osmoregulation and concludes that this critical salinity zone is hospitable to neither marine nor freshwater species. Therefore, any effects on fishery populations from changes in marsh-water patterns are thought to be minimal. Long-term effects of diversions on marsh-water patterns, however, are unknown. Nevertheless, recent work by De Mutsert (Department of Oceanography and Coastal Sciences, LSU, personal communication) show that the nursery function of marshes in Breton Sound appears to have increased in response to the Caernarvon diversion. Historical catches in the Louisiana Department of Wildlife and Fisheries resource survey data were used to create a before-after-control-impact analysis comparing juvenile fish abundance and salinity data from 1986 to 2007 at stations that have received diversion waters with those isolated from them. Of the 134 species studied, the most significant changes postopening are increases of Sciaenops ocellatus, Mugil cephalus, and Cynoscion nebulosus. The six Louisiana coastal area nekton species of interest, which include Cynoscion nebulosus, Micropterus salmoides, Brevoortia patronus, Micropogonias undulatus, Farfantepenaeus aztecus, and Litopenaeus setiferus, were not negatively affected by the opening of the diversion; rather, small increases are apparent for each species. The results indicate complex interactions between river-water inflow and community composition in which salinity changes, alterations in energy flow, and food web interactions together play a role.

The spatial distribution of nekton in estuaries appears strongly influenced by water temperature and salinity patterns (Barrett and Gillespie, 1975; Ford and St. Amant, 1971; Gunter, 1961; Haas et al., 2001; Martino and Able, 2003; Upchurch and Wenner, 2008; Weinstein Weiss, and Walters, 1980), and both of these environmental variables are affected by inflows from river diversions. Of course, the magnitude of any effect depends on the characteristics of the river water at the time of a diversion and the volume of freshwater inflow relative to the total volume of the receiving estuary. The response by aquatic organisms to such environmental change is species dependent. Because the river water diverted into the Breton Sound estuary is usually cooler than estuarine waters (Lane, Day, and Thibodeaux, 1999; Lane et $a l ., 2007)$ and growth rates of fishes and invertebrates are strongly regulated by temperature, these inflows could potentially reduce growth rates and the productivity of fishery species. Monitoring during diversions does show that water temperature in the estuary below the Caernarvon structure is lowered by inflows of river water, but the effect is limited to a relatively small area (Lane, Day, and Thibodeaux, 1999; Lane et al., 2007). It is likely that diversions in the late spring (April-June) at the time of maximum brown shrimp abundance will depress brown shrimp production. The effect of inflows on estuarine temperatures, however, should be considered in designing and operating larger capacity diversions planned for the future.

Freshwater inflows from diversions also alter estuarine salinity patterns. Inflows that shift isohalines seaward allow freshwater species to extend their distribution down estuary, whereas estuarine-marine species may be temporarily displaced from estuarine nursery areas freshened by these inflows. Caernarvon pre- and postconstruction monitoring of the Breton Sound estuary indicates that following the diversion, juvenile brown shrimp abundance initially decreased, but since then, brown shrimp catches have increased to near preconstruction levels (LDNR, 2006; Chuck Villarrubia, LDNR, personal communication,). In a study conducted following freshwater releases from the Caernarvon diversion in winter 2000 and spring 2001, sulfur stable isotope $\left(\delta^{34} \mathrm{~S}\right)$ analysis indicated that brown shrimp had been displaced downstream by these releases, but by May had returned to the inflow area (Rozas et al., 2005). Largemouth bass and alligator populations, and seed and sack oyster production have clearly increased, whereas white shrimp, blue crab, and red drum abundances either increased or have not changed since the Caernarvon diversion began operating (LDNR, 2006). The effects of other diversions, however, may differ from the Caernarvon diversion. After the Colorado River was reconnected to Matagorda Bay, Texas, in 1992, salinity, species richness, and the abundance of brown shrimp and Atlantic croaker were all reduced significantly within eastern Matagorda Bay, the portion of the estuary near the diversion (Wilber and Bass, 1998). Oyster landings also decreased following the diversion with the loss of previously harvestable reefs located near the redirected river mouth (Wilber and Bass, 1998). No change was detected in populations of white shrimp, blue crab, or spot following the diversion (Wilber and Bass, 1998). Monitoring of the Caernarvon effects suggests inflows from the diversion may have changed the spatial distribution of some fishery populations but not reduced the size of these populations. Diversion structures of much larger capacity than the one at Caernarvon, however, are being planned, and the operation of these projects may cause significant changes in estuarine fishery populations. Where diversions freshen an estuary enough to significantly expand fresh and intermediate marsh zones at the expense of 
brackish and saline zones, populations of fishery species such as brown shrimp, white shrimp, blue crab, and spotted seatrout are expected to decline (Reed et al., 2007).

We think it is important to point out, however, that the decline described by Reed et al. (2007), as well as several of the other changes mentioned previously, are local and may best be categorized as effects rather than impacts. In recent EcopathwEcosim model simulations based upon ongoing work in Breton Sound, the work of De Mutsert (personal communication, unpublished data) demonstrates that while community composition and species-specific centers of abundance within an estuarine basin are likely to shift when water is diverted into the estuary, net changes in basin-scale population biomass are negligible. Even though species redistribute, community composition averaged over the basin also remain unchanged.

In cases of much larger diversions, we expect more substantial effects to occur, both upon community composition and species-specific centers of abundance. If large enough, the addition of freshwater within an estuarine basin could have significant effects on the fisheries for some species. For example, yields of brown shrimp, white shrimp, blue crab, and spotted seatrout could decline, whereas fisheries for largemouth bass and mullet could increase. Tradeoffs such as these will necessarily be an important part of the discussion about how diversions should be operated. This issue is even more complex for oysters because they are sessile. Clearly, diversion operation will remain important to the maintenance and enhancement of oyster reefs that are affected by diversions of any size, as has been demonstrated by the controversy over current operation of the Caernarvon Diversion, and the proposed construction of the Violet Diversion to enhance oyster production in Mississippi Sound. Nevertheless, a number of investigations, in the Gulf of Mexico and elsewhere, have demonstrated strong positive relationships between yields of finfishes and decapod crustaceans and estuarine primary production (Cushing, 1996; Deegan, 1986; Iverson, 1990; Nixon, 1988), suggesting the transfer of energy among trophic levels within healthy estuaries is quite efficient, albeit trophic linkages and mechanisms that promote high secondary production in estuaries still are poorly known (Cowan, Grimes, and Shaw, 2008). However, because estuaries serve as nursery areas for many fishes and invertebrates that spawn offshore, enter the estuary as postlarvae and, after a period of juvenile residency, move back offshore to complete their life cycles, redistribution is a normal part of the estuarine dependency paradigm. We argue then that healthy deltaic ecosystems will have processbased dynamical characteristics, e.g., tighter coupling of production cycles and higher turnover rates (production : biomass) that promote trophic efficiency, and that the impacts on fisheries resources at the ecosystem-scale of large diversions will likely be significant and overwhelmingly positive (Cowan, Grimes, and Shaw, 2008). This admonition recognizes that small changes in vital rates such as growth can cause order of magnitude or greater changes in the numbers of individuals surviving to recruitment; increased growth rates of a fraction as low as $10 \%$ of the population of larval
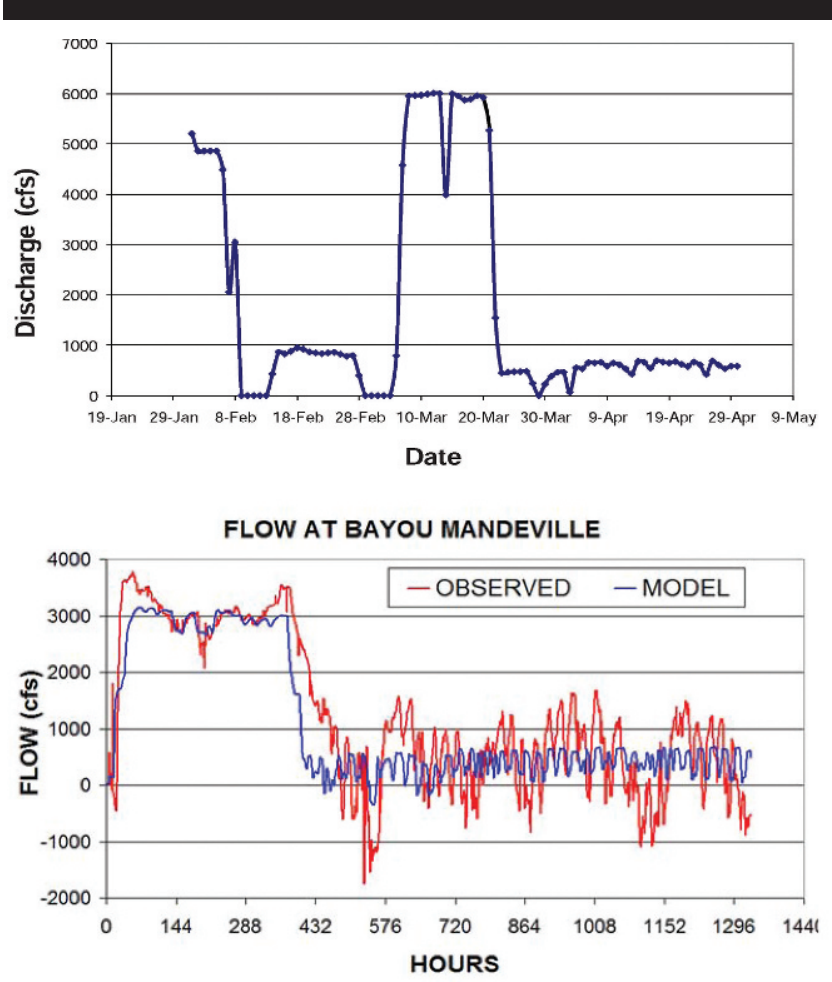

Flow at Delacroix Canal

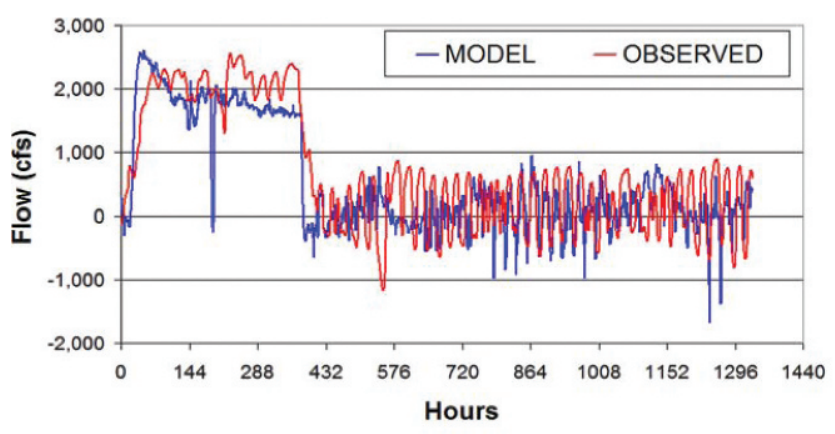

Figure 11. Upper panel: measured outfall discharge during the March 2001 PULSES experiment; middle panel: comparison of observed and simulated flows at Bayou Mandeville; lower: comparison of observed and simulated flows at Delacroix Canal. The time zero in the calibration plots corresponds to the start of the experiment (March 7, 2001) indicated in the upper panel.

and juvenile fishes and invertebrates can compensate for losses if none of the remaining $90 \%$ survive (Houde, 1989).

\section{Modeling}

Our research setting was unique in that we manipulated the duration and magnitude of freshwater pulses, and this presented an excellent opportunity for model calibration and validation. Predicted flows (Figure 11) and Chl $a$ levels (Figure 12) generally have shown good agreements with the measured values. For example, during the March 2001 experiment (Figure 11), observed Chl a concentrations ranged from 3 to $10 \mu \mathrm{g} \mathrm{L}^{-1}$ in Lake Leary to 30 to $40 \mu \mathrm{g} \mathrm{L}^{-1}$ 

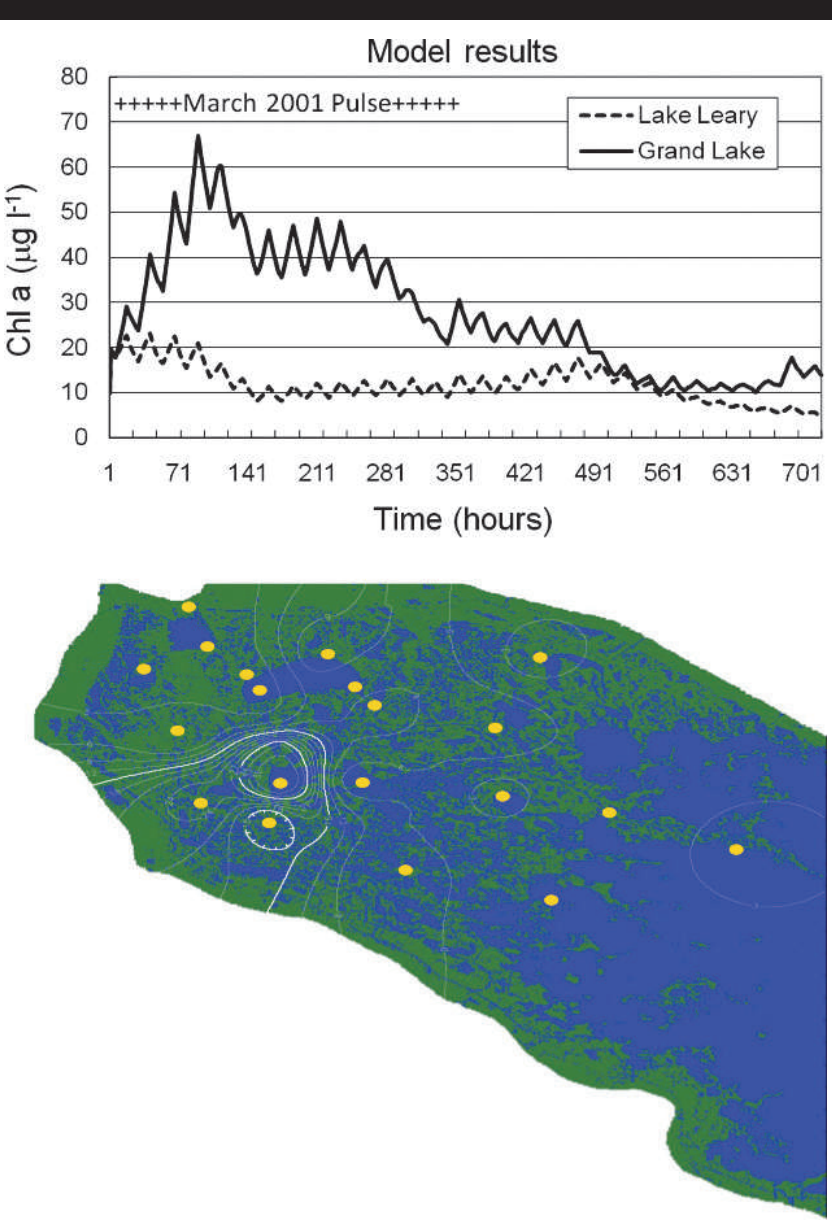

Figure 12. Upper panel: comparison between simulated Chl $a$ concentrations in Lake Leary and Grand Lake during the March 2001 PULSES experiment. Lower panel: $\mathrm{Chl} a$ concentrations $\left(\mu \mathrm{g} \mathrm{L}{ }^{-1}\right)$ measured on March 15, 2001. The model accurately reproduced the occurrence of phytoplankton bloom in Grand Lake (lower panel). Yellow circles are sampling stations.

in Grand Lake (Figure 12). Interestingly, model simulations predicted Chl $a$ values $>60 \mu \mathrm{g} \mathrm{L}^{-1}$ in Grand Lake, approximately 1 to 2 weeks after the start of the diversion (Figure 12). The model calculated residence times to range from 2 to 26 days (Figure 13). The observed phytoplankton growth rates in the Breton Sound estuary range between 0.05 and 0.55 doublings per day. Consequently, high residence areas of the Breton Sound estuary appear favorable for phytoplankton bloom development (>60 $\mu \mathrm{g} \mathrm{L}^{-1}$; Figure 12).

\section{SUMMARY, CONGLUSIONS, AND RECOMMENDATIONS}

Breton Sound estuary is the receiving basin for the Caernarvon freshwater river diversion in Louisiana and served as a model for investigations into physical and ecological responses of the estuary to pulsed Mississippi River inputs. Our results showed river diversions may be effective coastal restoration tools, with efficiency of the tool
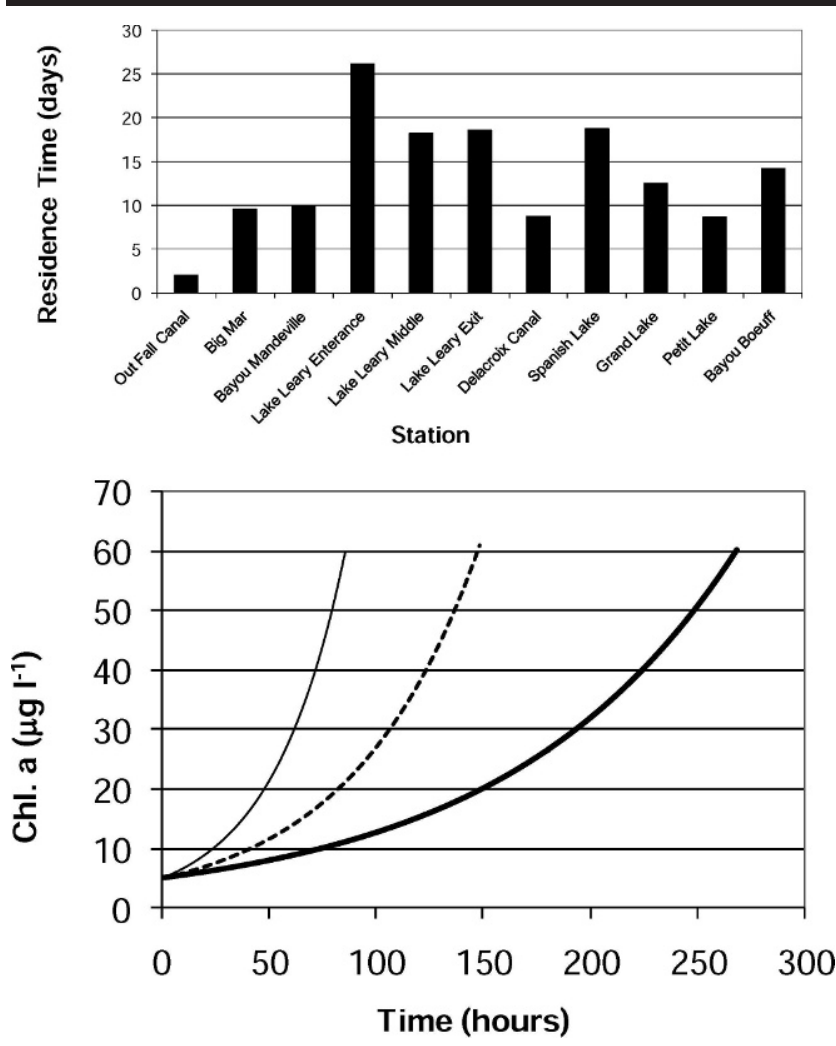

Figure 13. Upper: comparison of simulated residence times ( $75 \%$ removal rate) for various sections of the Breton Sound estuary. Lower: phytoplankton biomass increase as a function of growth rate and water residence time; solid line: 1 doubling per day; dashed line: 0.5 doublings per day; thick solid line: 0.25 doublings per day.

increasing with proximity to riverine source and degree of hydrologic alteration, quantity of river water released, and land uses of the receiving wetland basin. Landscape modifications such as spoil banks associated with oil and gas access canals can negate the benefits of river water introduction by limiting wetland-water interaction and should be removed in conjunction with river diversion implementation for effective wetland restoration. Concern is still present, however, that river nutrient loading can alter the phytoplankton community and potentially lead to eutrophication.

The Caernarvon diversion makes a significant contribution of freshwater to the Breton Sound estuary, which led to more rapid flushing of the estuary during the study period. Because of the freshwater input, potential impacts associated with drought years, such as saltwater intrusion, can be alleviated. Additionally, as diversion discharge increases, more water flows over marsh as sheet flow, thus increasing marsh water interactions. The timing of diversion discharge strongly affects the delivery of sediment to the estuary. Diverted river water inputs during rising or peak Mississippi River stage can deliver two or more times as much sediment per unit of water diverted as compared with diversions operated during falling river stages. As river water flows over the marsh, almost all suspended sediments are captured within a short distance into the marsh. Short term sediment 
deposition were equivalent to accretion rates as high as $2.3 \mathrm{~cm} \mathrm{y}^{-1}$ but longer term annual and decadal accretion is lower $\left(0.26-0.30 \mathrm{~cm} \mathrm{y}^{-1}\right)$ because of consolidation, compaction, and decomposition of organic matter. Measurements of vertical accretion and wetland surface elevation changes indicate Breton Sound wetlands are keeping up with local relative sea level rise.

Decreases in suspended sediments and nutrients occur as diverted river water flows down-estuary and over the marsh. Over-marsh flow is very efficient in removing nitrate because of the slow water flow and warmer temperatures. Decreases in concentrations of suspended sediments and most nutrients in the wetland-dominated part of the system above Breton Sound are nonconservative, showing that the estuary is acting as a sink. Denitrification is a major pathway for nitrogen removal. Significant changes in stoichiometric nutrient ratios are attributed to high removal rates of nitrate. Chlorophyll $a$ concentrations were low during pulsed discharge from the diversion but higher in the midestuary during warmer months. The diversion was the major source of freshwater and most nutrients to the estuary. Nutrient loading rates were low, leading to nonconservative uptake of most nutrients.

Nevertheless, the phytoplankton community bloomed in the summer after a period of diversion discharge, indicating some effect of the nutrient loading may be occurring. The phytoplankton community was dominated by diatoms, chlorophytes, and cyanobacteria, with a strong spatial, seasonal, and interannual variability. Cyanobacteria were highest during summer and fall when temperatures were high and flushing was low. Stable isotope analysis confirmed the diversion was an important source of materials supporting food webs in Breton Sound estuary, and this effect was greatest near the diversion. Submerged aquatic vegetation coverage was higher in the area most affected by the diversion. The increase in SAV is expected to benefit nekton unless growth becomes excessive and results in nighttime hypoxia. Biomass, density, and growth rates of freshwater nekton species were also greatest in areas affected by the diversion. The impacts of the diversion on estuarine species are complex and related to freshwater inflow, salinity changes, alterations in energy flow, and food web interactions. Overall, results suggest the diversion has altered the spatial patterns of nekton but has not reduced the size of these populations.

Plugging some canals and removing some spoil banks may help move more water over marsh vs. being captured in channels, but inadvertent impoundment of water over the marsh would be detrimental. It is apparent that diverting river water on rising and cresting Mississippi River stages maximizes sediment input to the basin. Monitoring wind direction and frontal passages when determining diversion discharge rates will also be important. If winds are from the south and stack water up in the upper basin, then more diverted river will flow over marshes. But the diversion should be operated in a way that also promotes rapid marsh drainage so that consolidation can take place. Otherwise prolonged inundation can lead to marsh deterioration. Sediment concentrations could be augmented in diverted river water to compensate for increasing relative sea level rise by pumping dredged material into water flowing through the diversion when flows are greater than $100 \mathrm{~m}^{3} \mathrm{~s}^{-1}$. Removal of upstream dams in the Mississippi River watershed and allowing sediment to bypass them will also increase the sediment load of the Mississippi River and greatly improve the effectiveness of coastal restoration plans for the Gulf of Mexico.

Greater flushing of parts of the estuary would be beneficial by reducing the potential for algal blooms. Increases in overmarsh flow to enhance sediment retention and increase temperature increases nutrient uptake. Diverting river water on higher river stages, and when southerly winds are present, may increase flushing and reduce phytoplankton abundance. Implications for phytoplankton management include avoiding higher diversion discharges under high light and high temperature regimes, carrying out diversions in the winter and spring, and changing hydrology to reduce residence time.

The young of fishery species show distinct seasonal abundance patterns in estuaries (Rakocinski, Baltz, and Fleeger, 1992; Rogers and Herke, 1985; Rozas et al., 2007), and these patterns should be considered when developing operational plans for river diversions to lessen potential impacts of inflows to fishery populations. As such, if the intent is to protect existing fisheries, sediment introductions and high freshwater flows should be diverted directly into the fresh and intermediate marsh zones where the need is high and the potential effects (e.g., the redistribution of adults within and between estuarine basins) would be less than in the brackish and saline marsh zones (see Reed et al., 2007). For example, the structure could be operated to deliver highpulse flows every few years when the river is at flood stage, and in nonflood years, lesser, pulsed flows would be allowed only in winter and early spring. In this scenario, high flow years could be selected to coincide with El Niño events when brown shrimp populations already would be relatively low (Piazza, 2009). The catch may be reduced during high-flow years, but benefits (e.g., increased fishery production) would accrue during intervening years, and over the long term, marsh loss would likely be reversed. However, if the intent is to improve nursery function, freshwater diversions should be operated to vary flows seasonally and annually to mimic fluctuations that occurred before the river and estuary were decoupled (Cowan, Grimes, and Shaw, 2008). In cases of large diversions, we expect more substantial effects to occur, both on community composition and species-specific centers of abundance. However, because estuaries serve as nursery areas for many fishes and invertebrates that spawn offshore, enter the estuary as postlarvae and, after a period of juvenile residency, move back offshore to complete their life cycles, redistribution is a normal part of the estuary-dependency paradigm. There are a number of potential problems with diversions, including low dissolved oxygen, bioaccumulation of heavy metals, and possible weakening of marsh substrate. These should be addressed in future studies of diversions.

\section{ACKNOWLEDGMENTS}

We dedicate this paper to the memory of Dr. Shea Penland who worked tirelessly to understand coastal processes and in advocating for restoring coastal wetlands and barrier islands 
in Louisiana. This work was supported by the U.S. Environmental Protection Agency Water and Watersheds Program (\#R828009), the USDA CREES (\#2002-00561), and the Louisiana Department of Natural Resources (\#2503-01-27). We thank the Caernarvon Interagency Advisory Committee of stakeholders and Delacroix Corporation for their cooperation and support. We also thank the many unheralded students and colleagues who spent time in the field or laboratory throughout these studies. The suggestions of two anonymous reviewers improved the original manuscript. The findings, conclusions, and recommendations presented in this paper are those of the authors and do not necessarily represent the views of the NOAA Fisheries Service.

\section{LITERATURE CITED}

Baker, J., 2005. A Flume Technique to Measure Marsh Nutrient Flux in Coastal Wetlands Associated with a Mississippi River Diversion. Lafayette, Louisiana: University of Louisiana at Lafayette, Master's thesis, $72 \mathrm{p}$.

Barras, J.A., 2007. Satellite Images and Aerial Photographs of the Effects of Hurricanes Katrina and Rita on Coastal Louisiana: U.S. Geological Survey Data Series 281. http://pubs.usgs.gov/ds/2007/ 281 (accessed September 8, 2009).

Barras, J.A.; Bourgeois, P.E., and Handley, L.R., 1994. Land Loss in Coastal Louisiana, 1956-1990. National Biological Survey, National Wetlands Research Center Open File Report 94-01. Lafayette, Louisiana: National Biological Survey.

Barrett, K.R., 1996. Two-Dimensional Modeling of Flow and Transport in Treatment Wetlands: Development and Testing of a New Method for Wetland Design and Analysis. Evanston, Illinois: Northwestern University, Doctoral dissertation, 253p.

Barrett, B.B. and Gillespie, M.C., 1975. Primary Factors which Influence Commercial Shrimp Production in Coastal Louisiana. Louisiana Wildlife and Fisheries Commission Technical Bulletin Number 9. New Orleans, Louisiana: Louisiana Wildlife and Fisheries Commission.

Barrie, A. and Prosser, J., 1996. Automated analysis of light-element stable isotopes by isotope ratio mass spectrometry. In: Boutton, T.W. and Yamasaki, S.I. (eds.), Mass Spectrometry of Soils. New York: Dekker, pp. 1-46.

Baumann, R.; Day, J., and Miller, C., 1984. Mississippi deltaic wetland survival: sedimentation vs castal submerence. Science, 224, 1093-1095.

Boesch, D.F.; Josselyn, M.N.; Mehta, A.J.; Morris, J.T.; Nuttle, W.K.; Simenstad, C.A., and Swift, D.J., 1994. Scientific assessment of coastal wetland loss, restoration and management in Louisiana. Journal of Coastal Research, Special Issue No. 20, pp. 1-103.

Boumans, R. and Day, J., 1993. High precision measurements of sediment elevation in shallow coastal areas using a sedimentationerosion table. Estuaries, 16, 375-380.

Boynton, W.; Kemp, W., and Keefe, C., 1982. A comparative analysis of nutrients and other factors influencing estuarine phytoplankton production. In: Kennedy, V. (ed.), Estuarine Comparisons. New York: Academic Press, pp. 69-90.

Britsch, L.D. and Dunbar, J.B., 1993. Land-loss rates: Louisiana coastal plain. Journal of Coastal Research, 9, 324-338.

Cahoon, D.; Martin, P.; Black, B., and Lynch, J., 2000. A method for measuring vertical accretion, elevation, and compaction of soft, shallow-water sediments. Journal of Sedimentary Research, 70, 1250-1253.

Capps, S.A. and Willson, C.S. 2002. Modeling of a Mississippi River diversion into Maurepas swamp. In: Proceedings of Coastal Water Resources Spring Specialty Conference, New Orleans, Louisiana. American Water Research Association, pp. 189-194.

Carmen, K. and Fry, B., 2002. $\delta 13 \mathrm{C}$ and $\delta 15 \mathrm{~N}$ analysis of meiofaunal species from a coastal marsh. Marine Ecology Progress Series, 240, 85-92.

Chabreck, R.H. 1971. Ponds and lakes of the Louisiana coastal marshes and their value to fish and wildlife. Proceedings of the Southeast Association of Game and Fish Commissions, 25, 206-215.

Childers, D.L. and Day, J.W., Jr., 1988. A flow-through flume technique for quantifying nutrient and material fluxes in microtidal estuaries. Estuarine and Coastal Shelf Science, 27, 483-494.

Chuang, W. and Wiseman, W., 1983. Coastal sea level responses to frontal passages on the Louisiana-Texas shelf. Journal of Geophysical Research, 88, 2615-2620.

Cowan, J.H., Jr.; Grimes, C.B., and Shaw, R.F., 2008. Life history, history, hysteresis and habitat changes in Louisiana's coastal ecosystem. Bulletin of Marine Science, 83, 197-215.

Cushing, D.H., 1996. Population Production and Regulation in the Sea. A Fisheries Perspective. Cambridge, U.K.: Cambridge University Press.

Darby, F.A. and Turner, R.E., 2008a. Below- and aboveground Spartina alterniflora production in a Louisiana salt marsh. Estuaries and Coasts, 31, 223-231.

Darby, F.A. and Turner, R.E., 2008b. Effects of eutrophication on salt marsh root and rhizome biomass accumulation. Marine Ecology Progress Series, 363, 63-70.

Davis, D.W., 1993. Crevasses on the lower course of the Mississippi River. Coastal Zone, 1, 360-378.

Davis, D.W., 2000. Historical perspective on crevasses, levees, and the Mississippi River. In: Colten, C.E. (ed.), Transforming New Orleans and Its Environs, Pittsburgh, Pennsylvania: University of Pittsburgh Press, pp. 84-106.

Day, J.; Boesch, D.; Clairain, E.; Kemp, P.; Laska, S.; Mitsch, W.; Orth, K.; Mashriqui, H.; Reed, D.; Shabman, L.; Simenstad, C.; Streever, B.; Twilley, R.; Watson, C.; Wells, J., and Whigham, D. 2007. Restoration of the Mississippi Delta: lessons from Hurricanes Katrina and Rita. Science, 315, 1679-1684.

Day, J.; Hall, C.; Kemp, M., and Yáñez-Arancibia, A., 1989. Estuarine Ecology. New York: Wiley Interscience. 576p.

Day, J.; Lane, R.; Moerschbaecher, M.; DeLaune, R.; Twilley, R.; Mendelssohn, I., and Baustian, J., 2009. The impact of the Caernarvon diversion on above and belowground marsh biomass in the Breton Sound estuary after Hurricane Katrina. Final Report submitted to the Louisiana Department of Natural Resources. Project Number 2512-07-01.

Day, J.; Martin, J.; Cardoch, L., and Templet, P., 1997. System functioning as a basis for sustainable management of deltaic ecosystems. Coastal Management, 25, 115-154.

Day, J.; Pont, D.; Hensel, P., and Ibañez, C., 1995. Impacts of sea-level rise on deltas in the Gulf of Mexico and the Mediterranean: the importance of pulsing events to sustainability. Estuaries, 18(4), 636-647.

Day, J.; Shaffer, G.; Britsch, L.; Reed, D.; Hawes, S., and Cahoon, D., 2000. Pattern and process of land loss in the Mississippi delta: a spatial and temporal analysis of wetland habitat change. Estuaries, 23, 425-438.

Day J.W.; Ko, J.-Y.; Rybczyk, J.; Sabins, D.; Bean, R.; Berthelot, G.; Brantley, C.; Cardoch, L.; Conner, W.; Day, J.N.; Englande, A.J.; Feagley, S.; Hyfield, E.; Lane, R.; Lindsey, J.; Mitsch, J.; Reyes, E. and Twilley, R., 2004. The use of wetlands in the Mississippi delta for wastewater assimilation: a review. Ocean and Coastal Management, 47, 671-691.

Deegan, L.A. 1986. Changes in body composition and morphology of young-of-the-year gulf menhaden, Brevoortia patronus Goode, in Fourleague Bay, Louisiana. Journal of Fish Biology, 29, 403-415.

DeLaune, R.D.; Jugsujinda, A.; Peterson, G.W., and Patrick, W.H., 2003. Impact of Mississippi River freshwater reintroduction on enhancing marsh accretionary processes in a Louisiana estuary. Estuarine, Coastal and Shelf Science, 58, 653-662.

Delaune, R.D. and Pezeshki, S.R., 2003. The role of soil organic carbon in maintaining surface elevation in rapidly subsiding U.S. Gulf of Mexico coastal marshes. Water, Air, and Soil Pollution, 3, 167-179.

De Mutsert, K. and Cowan, J.H., Jr., 2009. A BACI conducted an analysis to study the effects of a Mississippi freshwater diversion on estuarine fish community composition in Louisiana, USA. The Open Fish Science Journal, in press.

Eldridge, P.M. and Cifuentes, L.A., 2001. A stable isotope model approach to estimating the contribution of organic matter from 
marshes to estuaries. In: Weinstein, M.P. and Kreeger, D.A. (eds.), Concepts and Controversies in Marsh Ecology. Dodrecht, Netherlands: Kluwer Academic Publishers, pp. 495-513.

EMRL (Environmental Modeling Research Laboratory), 2002. Surface Water Modeling System (SMS) Reference Manual. Provo, Utah: Environmental Modeling Research Laboratory, Brigham Young University.

Fisher, T.; Harding, L., and Stanley D., 1988. Phytoplankton, nutrients, and turbidity in the Chesapeake, Delaware, and Hudson estuaries. Estuarine Coastal and Shelf Science, 27, 61-93.

Ford, T.B. and St. Amant, L.S., 1971. Management guidelines for predicting brown shrimp, Penaeus aztecus, production in Louisiana. Proceedings of the Gulf and Caribbean Fisheries Institute, 23, 149 161.

Freeman, G.E., 1992. Solving the Dilemma: To Wave or to Oscillate? Opposing Formulations of the Shallow Water Equations in River Modeling, Volumes 1 and 2. College Station, Texas: Texas A\&M University, Doctoral dissertation, 448p.

Greenberg, A.E.; Trussell, R.R.; Clesceri, L.S., and Franson, M.A.H. (eds.), 1985. Standard Methods for the Examination of Water and Wastewater. Washington D.C.: American Public Health Association.

Gunter, G. 1961. Some relations of estuarine organisms to salinity. Limnology and Oceanography, 6, 182-190.

Hass, H.L.; Lamon, E.C., III; Rose, K.A., and Shaw, R.F., 2001. Environmental and biological factors associated with the stagespecific abundance of brown shrimp (Penaeus aztecus) in Louisiana: applying a new combination of statistical techniques to long-term monitoring data. Canadian Journal of Fisheries and Aquatic Sciences, 58, 2258-2270.

Houde, E.D., 1989. Subtleties and episodes in the early life of fishes. Journal of Fish Biology, 35, 29-38

Hyfield, E.; Day, J.W.; Cable, J.E., and Justic, D., 2008. The impacts of reintroducing Mississippi River water on the hydrologic budget and nutrient inputs of a deltaic estuary. Ecological Engineering, 32, 347-359.

Iverson, R.L., 1990. Control of marine fish production. Limnology and Oceanography, 35, 1593-1604.

Junk, W. and Bayley, P., 2008. The scope of the flood pulse concept regarding riverine fish and fisheries, given geographical and manmade differences among systems. In: Nielsen, J., Dodson, J., Friedland, K., Hamon, T., Musick, J., and Verspoor, E. (eds.), Reconciling Fisheries with Conservation. Proceedings of the First World Fisheries Conference. Bethesda, Maryland: American Fisheries Society, pp. 1907-1923.

Kemp, W. and Boynton, W., 1984. Spatial and temporal coupling nutrient inputs to estuarine primary prodution: the role of particulate matter transport and decomposition. Bulletin of Marine Science, 14, 185-196.

Lane, R.; Day, J.W., and Day, J.N., 2006. Wetland surface elevation, vertical accretion, and subsidence at three Louisiana estuaries receiving diverted Mississippi River water. Wetlands, 26, 1130-1142.

Lane, R.R.; Day, J.W.; Justic, D.; Reyes, E.; Marx, B.; Day, J.N., and Hyfield, E., 2004. Changes in stoichiometric Si, N and $\mathrm{P}$ ratios of Mississippi River water diverted through coastal wetlands to the Gulf of Mexico. Estuarine Coastal and Shelf Science. 60, 1-10.

Lane, R.R.; Day, J.W., Jr.; Kemp, G.P., and Marx, B., 2002. Seasonal and spatial water quality changes in the outflow plume of the Atchafalaya River, Louisiana, USA. Estuaries 25, 30-42.

Lane, R.; Day, J.W.; Marx, B.; Reyes, E.; Hyfield, E., and Day, J.N., 2007. The effects of riverine discharge on temperature, suspended sediments, and chlorophyll a in a Misssissippi delta estuary measured using a flow-thorough system. Estuarine and Coastal Shelf Science, 74, 145-154.

Lane, R.; Day, J., and Thibodeaux, B., 1999. Water quality analysis of a freshwater diversion at Caernarvon, Louisiana. Estuaries, 2A, 327-336.

Leonard, L., 1997. Controls of sediment transport and deposition in an incised mainland marsh basin, southeastern North Carolina. Wetlands, 17, 263-274.

Levinton, J.S., 2001. Marine Biology, 2nd Edition. Oxford, UK: Oxford University Press. 515p.

LDNR (Louisiana Department of Natural Resources), 2006. Caernar- von Freshwater Diversion Project, 2005 Annual Report. http://dnr louisiana.gov/crm/coastres/project.asp?id=BS-08 (accessed September 8, 2009), 50p.

Madden, C.; Day, J., and Randall, J., 1988. Coupling of freshwater and marine systems in the Mississippi deltaic plain. Limnology and Oceanography, 4(33, 2), 982-1004.

Martino, E.J. and Able, K.W., 2003. Fish assemblages across the marine to low salinity transition zone of a temperate estuary. Estuarine, Coastal and Shelf Science, 56, 969-987.

Mayer, L.M.; Keil, R.G.; Macko, S.A.; Joye, S.; Ruttenberg, K., and Aller, R.C., 1998. Importance of suspended particulates in riverine delivery of bioavailable nitrogen to coastal zones. Global Biogeochemical Cycles, 12, 573-579.

Minello, T.J. 1999. Nekton densities in shallow estuarine habitats of Texas and Louisiana and the identification of essential fish habitat. In: Benaka, L. (ed.), Fish Habitat: Essential Fish Habitat and Habitat Rehabilitation. American Fisheries Society Symposium volume 22, pp. 43-75.

Minello, T.J. and Rozas, L.P., 2002. Nekton in Gulf coast wetlands: fine-scale distributions, landscape patterns, and restoration implications. Ecological Applications, 12, 441-455.

Minello, T.J.; Zimmerman, R.J., and Medina, R., 1994. The importance of edge for natant macrofauna in a created salt marsh. Wetlands, 14, 184-198.

Mitsch, W.J. and Gosselink, J.G., 2007. Wetlands, 4th edition. New York: John Wiley \& Sons, Inc., 582p.

Mitsch, W.; Day, J.; Gilliam, J.; Groffman, P.; Hey, D.; Randall, G., and Wang, N., 2001. Reducing nitrogen loading to the Gulf of Mexico from the Mississippi River basin: strategies to counter a persistent problem. BioScience, 51(5), 373-388.

Mitsch, W.; Day, J.; Zhang, L., and Lane, R., 2005. Nitrate-nitrogen retention in wetlands in the Mississippi River basin. Ecological Engineering, 24, 267-278.

National Atmospheric Deposition Program, 2000-2002. National Atmospheric Deposition Program. http://nadp.sws.uiuc.edu (accessed September 8, 2009).

Nixon, S.W., 1981. Remineralization and nutrient cycling in coastal marine ecosystems. In: Neilson, B.J. and Cronin, L.E. (eds.), Estuaries and Nutrients. Clifton, New Jersey: Humana, pp. 111138.

Nixon, S.W., 1988. Physical energy inputs and the comparative ecology of lake and marine ecosystems. Limnology and Oceanography, 33, 1005-1025.

Odum, W.; Odum, E., and Odum, H.,1995. Nature's pulsing paradigm. Estuaries, 18, 547-555.

Penland, S.; Ramsey, K.E.; McBride, R.A.; Mestayer, J.T., and Westphal, K.A., 1988. Relative Sea Level Rise and Delta Plain Development in the Terrebonne Parish Region. Coastal Geology Technical Report. Baton Rouge, Louisiana: Louisiana Geological Survey, 121p.

Perez, B.; Day, J.; Rouse, L.; Shaw, R., and Wang, M., 2000. Influence of Atchafalaya River discharge and winter frontal passage on suspended sediment concentration and flux in Fourleague Bay, Louisiana. Estuarine, Coastal and Shelf Science, 50, 271-290.

Peterson, G.W. and Turner, R.E., 1994. The value of salt-marsh edge vs. interior as a habitat for fish and decapod crustaceans in Louisiana tidal marsh. Estuaries, 17, 235-262.

Piazza, B.P., 2009. The Role of Climate Variability in the Community Dynamics of Estuarine Nekton. Baton Rouge, Louisiana: Louisiana State University, Doctoral dissertation, 157p.

Piazza, B.P. and La Peyre, M., 2007. Restoration of the annual flood pulse in Breton Sound, Louisiana, USA: habitat change and nekton community response. Aquatic Biology, 1, 109-119.

Rakocinski, C.F.; Baltz, D.M., and Fleeger, J.W., 1992. Correspondence between environmental gradients and the community structure of marsh-edge fishes in a Louisiana estuary. Marine Ecology Progress Series, 80, 135-148.

Reed, D.J., 1992. Effect of weirs on sediment deposition in Louisiana coastal marshes. Environmental Management, 16, 55-65.

Reed, D.J.; Beall, A.; Martinez, L.; Minello, T.J.; O’Connell, A.M.; Rozas, L.P.; Penland, S.; Cashner, R.C., and Commagere, A.M., 2007. Modeling Relationships between the Abundance of Fishery Species, 
Coastal Wetland Landscapes, and Salinity in the Barataria Basin, Louisiana. Final report to NOAA National Marine Fisheries Service and the Louisiana Coastal Wetlands Conservation and Restoration Task Force, The University of New Orleans, 148p.

Richardson, C.J. and Nichols, D.S., 1985. Ecological analysis of wastewater management criteria in wetland ecosystems. In: Godfrey, P.J., Kaynor, E.R., and Pelczarski, S. (eds.), Ecological Considerations in Wetlands Treatment of Municipal Wastewaters. New York: Van Nostrand Reinhold, pp. 351-391.

Rivera-Monroy, V.H.; Day, J.W.; Twilley, R.R.; Vera-Herrera, F., and Coronado-Molina, C., 1995. Flux of nitrogen and sediment in a fringe mangrove forest in Terminos Lagoon, Mexico. Estuarine, Coastal and Shelf Science, 40, 139-160.

Roberts, H.H., 1997. Dynamic changes of the Holocene Mississippi river delta plain: the delta cycle. Journal of Coastal Research, 13 , 605-627.

Rogers, B.D. and Herke, W.H., 1985. Estuarine-dependent fish and crustacean movements and weir management. In: Bryan, C.F., Zwank, P.J., and Chabreck, R.H. (eds.), Fourth Coastal Marsh and Estuary Management Symposium. Baton Rouge, Louisiana: Louisiana State University Agricultural Center, pp. 201-219.

Roig, L.C., 1994. Hydrodynamic Modeling of Flows in Tidal Wetlands. Davis, California: University of California, Doctoral dissertation, $177 p$.

Rozas, L.P.; Minello, T.J.; Munuera-Fernandez, I.; Fry, B., and Wissel, B., 2005. Macrofaunal distributions and habitat change following winter-spring releases of freshwater into the Breton Sound estuary, Louisiana. Estuarine, Coastal and Shelf Science 65, 319-336.

Rozas, L.P.; Minello, T.J; Zimmerman, R.J., and Caldwell, P., 2007. Nekton populations, long-term wetland loss, and the effect of recent habitat restoration in Galveston Bay, TX (USA). Marine Ecology Progress Series, 344, 119-130.

Schram, H. and Eggleton, M., 2006. Applicability of the flood pulse concept in a temperate floodplain river ecosystem: thermal and temporal components. River Research and Applications, 22, 543-553.

Scruton, P.C., 1960. Delta building and the deltic sequence. Recent sediments. NW Gulf coast of Mexico. Tulsa, Oklahoma: American Association of Petroleum Geologists Special Publication, pp. 82102.

Snedden, G., 2006. River, tidal, and wind interactions in a deltaic estuarine system. Baton Rouge, Louisiana: Louisiana State University, Doctoral dissertation, $104 \mathrm{p}$

Snedden, G.; Cable, J.; Swarzenski, C., and Swenson, E., 2007. Sediment discharge into a subsiding Louisiana deltaic estuary through a Mississippi River diversion. Estuarine Coastal and Shelf Science, 71, 181-193.

Snedden, G.; Cable, J., and Wiseman, W., 2007. Subtidal sea level variability in a shallow Mississippi River deltaic estuary, Louisiana. Estuaries and Coasts, 30, 802-812.

Stanford, J.; Lorang, M., and Hauer, F., 2005. The shifting habitat mosaic of river ecosystems. International Society of Limnology, 29, $1-14$.
Swarzenski, C.M.; Doyle, T.W.; Fry, B., and Hargis, T.G., 2008 Biogeochemical response of organic-rich freshwater marshes in the Louisiana delta plain to chronic river water influx. Biogeochemistry, 90, 49-63.

Swenson, E.M.; Cable, J.E.; Fry, B.; Justic, D.; Das, A.; Snedden, G., and Swarzenski, C., 2006. Estuarive flushing times influenced by freshwater diversions. Coastal Hydrology and Processes, 33, 403-412.

Thomas, W.A. and McAnally, W.H., Jr., 1990. User's Manual for the Generalized Computer Program Systems for Open Channel Flow and Sedimentation: TABS-2 System. Vicksburg, Mississippi: Waterways Experiment Station, Hydraulics Laboratory, U.S. Army Corps of Engineers.

Turner, R.E.; Dortch, Q., and Rabalais, N.N., 2004. Inorganic nitrogen transformations at high loading rates in an oligohaline estuary. Biogeochemistry, 68(3), 411-423.

Turner, R.E. and Streever, B., 2002. Approaches to Coastal Wetland Restoration: Northern Gulf of Mexico. The Hague, The Netherlands: SPB Academic Publishing.

Twilley, R. and Rivera-Monroy, V., 2009. Sediment and nutrient tradeoffs in restoring the Mississippi River delta: restoration vs eutrophication. Journal of Contemporary Water Research \& Education, 141, 1-6.

Upchurch, S. and Wenner, E., 2008. Fish and decapod crustacean assemblages from the Ashepoo-Combahee-Edisto Basin, South Carolina (1993-1999). Journal of Coastal Research, Special Issue No. 55, pp. 200-213.

Vörösmarty, C.; Syvitski, J.; Day, J.; de Sherbinin, A.; Giosan, L., and Paola, C., 2009. Battling to save the world's river deltas. Bulletin of the Atomic Scientists, March/April 65, 31-43.

Walker, N.; Huh, O.; Haag, A.; Babin, A.; Cable, J.; Snedden, G.; Braud, D.; Wilensky, D., and Prasad, K., 2003. A role for remote sensing in managing Mississippi River diversions. Backscatter, 14(1), Winter, 25-28.

Weinstein, M.P.; Weiss, S.L., and Walters, M.F., 1980. Multiple determinants of community structure in shallow marsh habitats, Cape Fear River Estuary, North Carolina, USA. Marine Biology, $58,227-243$

Welder, F.A., 1959. Processes of Deltaic Sedimentation in the Lower Mississippi River. Coastal Studies Institute Technical Report. Baton Rouge, Louisiana: Louisiana State University.

Wheelock, K.V., 2003. Pulsed River Flooding Effects on Sediment Deposition in Breton Sound Estuary, Louisiana. Baton Rouge, Louisiana: Louisiana State University, M.S. thesis, 149 p.

Wilber, D.H. and Bass, R., 1998. Effect of the Colorado River diversion on Matagorda Bay epifauna. Estuarine, Coastal and Shelf Science, $47,309-318$

Wissel, B. and Fry, B., 2005. Tracing Mississippi River influences in estuarine food webs of coastal Louisiana. Oecologia, 144, 659-683.

Wissel, B.; Gace, A., and Fry, B., 2005. Tracing river influences on phytoplankton dynamics in two Louisiana estuaries. Ecology, 86, 2251-2762. 